\title{
Newly Synthesized Benzothiazole Derived Ligand and its Co(III) and Ru(III) Complexes as Biological Potent Molecules: Chemical Preparation, Structure, Antimicrobial, in vitro and in vivo Cytotoxicity Studies
}

\author{
Syed Ibrahim ${ }^{1}$, Prakasha Gavisiddegowda ${ }^{1}$, Hemavathi Nagaraju Deepakumari ${ }^{2}$, \\ Shiva Prasad Kollur ${ }^{3}$, Nagaraja Naik ${ }^{1, *}$

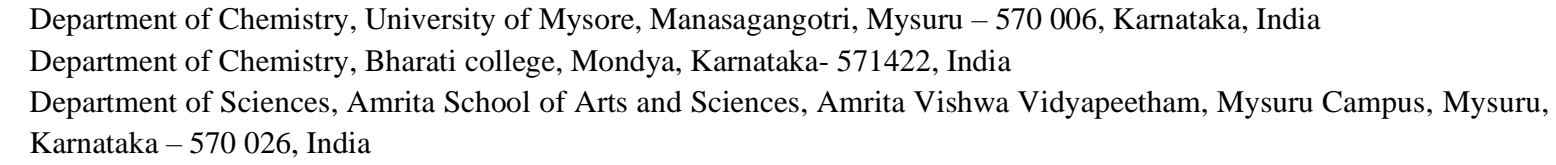

Scopus Author ID 7004879365

Received: 11.10.2021; Revised: 15.11.2021; Accepted: 20.11.2021; Published: 2.12.2021

\begin{abstract}
Herein we describe the synthesis of 2-((E)-(2-(benzo[d]thiazol-2-yl)phenylimino)methyl)-5methoxyphenol imine base (BMM) and its metal complexes such as $\left[\mathrm{Co}(\mathrm{BMM})_{2}\right] \mathbf{C 1},[\mathrm{Co}(\mathrm{BMM})(\mathrm{ph})]$ $\mathbf{C 2},\left[\mathrm{Ru}(\mathrm{BMM})_{2}\right] \mathbf{C 3}$ and $[\mathrm{Ru}(\mathrm{BMM})(\mathrm{ph})] \mathbf{C 4}$. The ligand and its complexes were characterized by spectroscopic, TGA, Powder X-ray diffraction (XRD), and elemental analysis. The coordination number and geometry were confirmed by various experimental data. The $\mathrm{Co}(\mathrm{III})$ and $\mathrm{Ru}$ (III) complexes are assigned to be having octahedral geometry. Further, the experimental results revealed that complex C2 and $\mathbf{C 4}$ emerged as moderate DNA binding intercalators compared to standard intercalators and prominent nuclease activity compared with $\mathbf{C 1}$ and $\mathbf{C} \mathbf{3}$ complexes. The extent of interaction and intercalation mode was confirmed by monitoring electronic absorption studies, fluorescence quenching probe, and viscosity measurement. Furthermore, the complexes C1-C4 were investigated for their in vitro cytotoxic studies against a panel of human cancer cell lines, viz., A549, NIH3T3, MCF-7, and EAC. Also, the cell adhesion and migration behavior were carried out after administering the complex $\mathbf{C} 2$ and $\mathbf{C} 4$ to respective cancer cell lines. In mice, the toxicities and tolerabilities of the complex C2 and $\mathrm{C} 4$ were also investigated through in vivo studies. The resultant complexes were screened for their microbial inhibition studies through the good diffusion method. All the complexes display moderate microbial inhibition properties compared to their uncoordinated analog.
\end{abstract}

Keywords: benzothiazole; metal complexes; antimicrobial activity; CT-DNA.

(C) 2021 by the authors. This article is an open-access article distributed under the terms and conditions of the Creative Commons Attribution (CC BY) license (https://creativecommons.org/licenses/by/4.0/).

\section{Introduction}

Ample research attempts have been made to find the right pharmacophore to suppress the cancerous cells with depressing side effects. Many research findings have shown that the metal-based drugs are promising potentially active to halt the proliferation of cancer cells at the cellular level because of their biocompatibility and their endogenous involvement in several enzymes as co-factors. The Imine base metal complexes are low toxic, highly stable, and chemotherapeutically active scaffolds because of their ability to imitate bio-compounds [1].

In the current research, benzothiazole is an active pharmacophore and most privileged heterocyclic moiety in medicinal chemistry [2]. In addition to this benzothiazole system serves 
as an integral part of the various biomolecules in the living system [3]. It is also known to exhibit a wide range of biological properties, including anticancer, antimicrobial, antidiabetic, anticonvulsant, anti-inflammatory, antiviral, antitubercular, anti HIV activities with a broad spectrum of pharmacological properties [4-9]. Over a decade, benzothiazole chemistry was successfully exploited into coordination chemistry and incorporated imine base as ligand skeleton. This is due to the fact that the availability of active metal-binding sites such as ring $\mathrm{N}, \mathrm{S}$, and azomethine $\mathrm{N}$ together emerged as new potential metal-based drugs for various diseases [10], especially the 2-arylbenzothiazole [11] unit, which is under evolution for the promising potentially active chemotherapeutic agent [12]. This contributes to the significance of the benzothiazole nucleus in the line of discovering novel chemical entities towards leading drugs in the market to make human life more sustainable. In order to become a clinically active chemotherapeutic drug, the various interaction of the drug at the molecular level to the cellular level is essential [13]. Most of the chemotherapeutic target is DNA, so it is essential to explore the novel complexes for the DNA binding interaction studies from which kinetic and mechanistic pathways of the interaction can be understood in detail.

Herein, we have designed, tailored, and structured a new benzothiazole based imine

base 2-((E)-(2-(benzo[d]thiazol-2-yl) phenylimino) methyl)-5-methoxyphenol (BMM) complexes of $\mathrm{Co}(\mathrm{III})(\mathrm{C} 1, \mathrm{C} 2)$ and $\mathrm{Ru}(\mathrm{III})(\mathrm{C} 3, \mathrm{C} 4)$ metal ions. The binding interaction of CTDNA with complex C1-C4 was investigated thoroughly using Uv absorption, fluorescence quenching, and viscosity methods, and pBR322 DNA is used to sketch DNA incision properties of $\mathrm{C} 4$ monitored by Gel electrophoretic pattern. Moreover, the bio-efficacy of C1-C4 has been interrogated against Gram-positive B. subtilis, S. aureus, and Gram-negative E. coli, P. aeruginosa. Further, the complexes were exploited for their in vitro chronic cytotoxicities against a panel of human cancer cell lines A549(liver), NIH-3T3, MCF-7(breast), and EAC. Furthermore, the in vivo chronic toxicity profiles of complex $\mathrm{C} 2$ and $\mathrm{C} 4$ were also studied on male and female mice's major organs (liver, kidney).

\section{Materials and Methods}

Benzothiazole, 4-methoxy salicylaldehyde, Acetic acid, piperidine, tris $\mathrm{HCl}$ buffer, Ethidium bromide, methanol, and DMSO were procured from Sigma Aldrich and Avra synthesis private limited, Bangalore, India. All the chemicals and the solvents were utilized without exposure to any purification technique. CT-DNA and BSA were purchased from Merck, Hyderabad, India, and stored at $4^{\circ} \mathrm{C}$. All solutions and buffers were made using triple distilled water to study DNA binding, DNA cleavage, and BSA interaction.

The reactions were monitored progressively by thin-layer chromatography on the Aluminum plate using $\mathrm{CHCl}_{3}: \mathrm{MeOH}(9: 1)$ as a mobile phase. The chemical composition of various elements $(\mathrm{C}, \mathrm{H}, \mathrm{N}, \mathrm{S})$ and their extent of distribution in Imine base and its metal complexes were analyzed by using Perkin Elmer $240^{\circ} \mathrm{C}$ (USA) elemental analyzer. FT-IR spectra of ligand and complexes were monitored in the range $4000-600 \mathrm{~cm}^{-1}$ on Shimadzu 8300 spectrophotometer using $\mathrm{KBr}$ pellets. ${ }^{1} \mathrm{H}$ NMR and ${ }^{13} \mathrm{C}$ NMR spectra of Imine base(BMM) give valuable information regarding the chemical environment around proton and carbon were done using Bruker 400MHz NMR spectrophotometer in DMSO and difference in absorption were recorded in ppm down the field from TMS as an internal reference. The melting point of complexes was determined on a Thomas Hoover capillary melting point apparatus with a digital thermometer which is uncorrected. The molecular weight of the Imine base and their 
metal complexes were identified from mass spectra of the compounds obtained on mass spectrometer through ESI technique. Electronic absorption spectra of the resultant complexes were recorded by UV visible spectrophotometer using DMSO as a solvent. The complexes' magnetic behavior was resolved using Guoy's balance with $\mathrm{Hg}\left[\mathrm{Co}(\mathrm{CN})_{4}\right]$ as a standard compound. Thermogravimetric examination (TGA and DTA) of complexes were recorded under dynamic nitrogen atmosphere with a heating rate of $10^{\circ} \mathrm{Cmin}^{-1}$ using the thermogravimetric instrument. EPR spectra are used to identify the environment of the magnetically active metal center in Ru(III) complexes using JES-FA200 ESR spectrometer (JEOL-Japan) at liquid nitrogen temperature. DNA binding studies were monitored by Electronic absorption titration using a Uv-visible spectrometer, fluorescence quenching method on Spectrofluorometer, and Viscosity measurement method using Ostwald's viscometer immersed in a thermostatic water bath with a temperature range of $30^{\circ} \mathrm{C} \pm 1{ }^{\circ} \mathrm{C}$.

\subsection{Chemical synthesis.}

2.1.1. Synthesis of 2-((E)-(2-(benzo[d]thiazol-2-yl)phenylimino)methyl)-5-methoxyphenol Imine base (BMM).

It is synthesized by heating an equimolar solution of 4-methoxy salicylaldehyde $(5 \mathrm{mmol})$ and 2-(2-aminophenyl) benzothiazole $(5 \mathrm{mmol})$ in $20 \mathrm{ml}$ hot methanol in the presence of the catalytic amount of acetic acid under a reflux condition over 4 hours, a yellow solid precipitated out. The completion of the reaction is monitored by TLC using a mixture of methanol and chloroform as a solvent in the ratio 9:1. The yellow crystalline solid precipitates were filtered, dried, and recrystallized from hot methanol. The ligand obtained in scheme 1 is soluble in methanol, DMSO, and chloroform.

Elemental analysis $\left(\mathrm{C}_{21} \mathrm{H}_{16} \mathrm{~N}_{2} \mathrm{O}_{2} \mathrm{~S}\right)$; Found (\%)-C-69.98, H-4.47, N-7.77 O-8.88, S8.90; ${ }^{1} \mathrm{H}-\mathrm{NMR}$ (DMSO-d6, $\left.400 \mathrm{MHz}, \mathrm{ppm}\right) \delta=5.06$ (s, 2H, CH2), 7.14 (d, 2H, Ar-H), 7.437.506(d, 2H, Ar-H), 7.57(s, 1H, Ar-H), 7.62 (s, 1H, Ar-H) 8.76 (s, 1H, N=CH), $12.51(\mathrm{~s}, 1 \mathrm{H}$, Ar-OH), 14.6 (s, 1H, NH in imidazole ring); ${ }^{13} \mathrm{C}-\mathrm{NMR}$ (DMSO-d6, $100 \mathrm{MHz}, \mathrm{ppm}$ ) $\delta 50.64$, 96.02, 102.32, 109.29, 115.36, 116.96, 117.90, 120.28, 121.25, 121.34, 121.51, 124.05, 127.17, 128.36, 131.14, 143.75, 147.22, 157.04, 157.43, 158.85, 159.33ppm (Figures S1 and S2). ESILCMS m/z cal.for $\mathrm{C}_{21} \mathrm{H}_{16} \mathrm{~N}_{2} \mathrm{O}_{2} \mathrm{~S} 227.06$ found 227.10, $\mathrm{M}+360.09$ found 361.15, $\mathrm{M}+1361.09$ found 362.15 (Figures S3- S7).

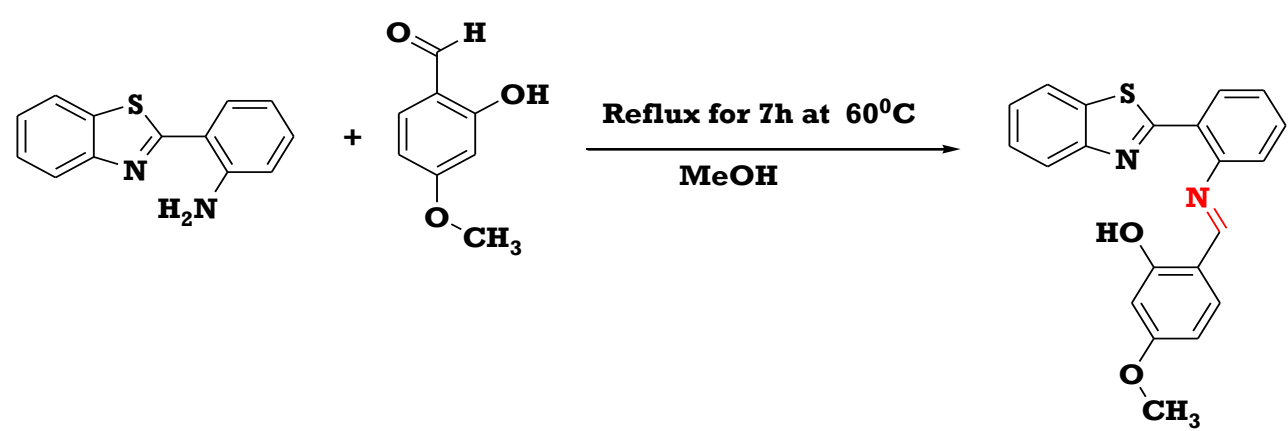

Scheme 1. Synthesis of 2-((E)-(2-(benzo[d]thiazol-2-yl)phenylimino)methyl)methoxyphenol(BMM)

2.1.2 Synthesis of $\mathrm{Co}(\mathrm{III})$ and $\mathrm{Ru}(\mathrm{III})$ complexes in the ratio 1:2 (C1 and $\mathrm{C} 3)$.

A dark brown and dark green color solutions are obtained when two equimolar solutions of 2-((E)-(2-(benzo[d]thiazol-2-yl) phenylimino) methyl)-5-methoxyphenol (BMM) (10mmol) is heated with one equimolar methanolic solution of metal salts $(5 \mathrm{mmol})(\mathrm{RuCl} 3.2 \mathrm{H} 2 \mathrm{O}$, 
$\mathrm{CoCl} 2.6 \mathrm{H} 2 \mathrm{O}$ ) under reflux condition over $7-8 \mathrm{hrs}$ on a water bath. The resultant solution is concentrated to its half volume and evaporated to dryness for several days at room temperature. The solid obtained was cracked carefully and collected for further spectral characterization.

2.1.3. Synthesis of $\mathrm{Co}(\mathrm{III})$ and $\mathrm{Ru}(\mathrm{III})$ complexes in the ratio 1:1 (C2 and $\mathrm{C} 4)$.

2-((E)-(2-(benzo[d]thiazol-2-yl) phenylimino) methyl)-5-methoxyphenol(5mmol) is dissolved in methanol and transferred to a round bottom flask containing a methanolic solution of metal salts $(5 \mathrm{mmol})\left(\mathrm{RuCl}_{3} \cdot 2 \mathrm{H} 2 \mathrm{O}, \mathrm{CoCl}_{2} \cdot 6 \mathrm{H}_{2} \mathrm{O}\right)$ which is heated to $1 \mathrm{hr}$. An auxiliary ligand 1,10 phenanthroline is added to the reaction mixture, which is further heated under reflux condition on the water bath for the next 6-7hrs. The resultant solution is concentrated to its half volume and evaporated to dryness for several days at room temperature. The solid obtained was cracked carefully and collected for further spectroscopic examination.

\subsection{Biological evaluations.}

\subsubsection{In vitro antimicrobial assay.}

The investigated metal complexes of $\mathrm{Co}(\mathrm{III})$ and $\mathrm{Ru}(\mathrm{III})$ metal ions derived from benzothiazole imine base motif (BMM) were examined for their in vitro antibacterial activity against Gram-positive B. subtilis (ATCC 21332), S. aureus(ATCC 700699), and Gramnegative E.coli(ATCC 0157:H7), P. aeruginosa (ATCC 15442). In order to measure the antibacterial efficacy of the complexes, the disc well diffusion method was implemented by using a nutrient agar medium. The bacterial strain was cultured in the sterile inoculation medium and incubated at $37{ }^{\circ} \mathrm{C}$, used after one day. The nutrient medium is mixed aseptically to get homogeneous concentration with $24 \mathrm{hr}$ grown bacterial culture on inoculation medium. Wells ( $8 \mathrm{~mm}$ in diameter) were punched into agar plates and introduced with $0.1 \mathrm{~mL}$ of the test complexes (stock solution $200 \mu \mathrm{M} / \mathrm{ml}$ in DMSO). Then the plates were incubated at $37^{\circ} \mathrm{C}$ after allowing the drug solution to diffusion for an hour. The zone of inhibition in $\mathrm{mm}$ was measured by comparing all the complexes' antimicrobial activity with the commercially available reference drug Doxycycline(100mg/disc) for antibacterial activity [14]. Further, MIC value will be taken for the lowest concentration (highest dilution) $(\mu \mathrm{M} / \mathrm{mL})$ of complex, which suppresses the growth of bacteria at $37^{\circ} \mathrm{C}$ after $24 \mathrm{hr}$ incubation. Separate studies were carried out to clarify the effects of DMSO on bacterial growth inhibition, and it was found that there is no indication of the reduction of microorganism growth. The given panel of resultant metal complexes (C1-C4) showed a moderate to significant activity in the series with MIC values ranging between $13-25 \mu \mathrm{g} / \mathrm{mL}$.

\subsubsection{DNA binding studies.}

\subsubsection{Electronic absorption titration.}

UV-Visible titration experiments are the most prominent and convenient method to quantify the binding interaction of metal complexes with CT-DNA in different modes. All the measurements concerned with DNA binding studies were carried out by using Tris-HCl buffer (5mM Tris-HCl/50mM NaCl buffer at $\mathrm{pH}-7.2)$. The absorption titrations were performed by successive addition of CT-DNA $(0.0-25 \mu \mathrm{M})$ against a fixed concentration of metal complex $(25 \mu \mathrm{M})$. The data were recorded for each incremental addition of CT-DNA after dilution with 
buffer at room temperature. The sodium salts of CT-DNA were prepared using tris - $\mathrm{HCl}$ buffer and stored at $4{ }^{\circ} \mathrm{C}$, which is used within 4 days. The complex free CT-DNA shows an absorption peak at $260 \mathrm{~nm}$, and $345 \mathrm{~nm}$ indicates that the nucleic acid is completely independent of protein moieties. The concentration of nucleotide was determined by measuring absorbance at $260 \mathrm{~nm}$ using molar extinction coefficient $6600 \mathrm{M}^{-1} \mathrm{~cm}^{-1}$. The required stock solution of metal complexes was dissolved in DMSO and diluted using Tris-HCl buffer [15]. The collected data were fitted to equation 1 and to get intrinsic binding constant $\left(\mathrm{k}_{\mathrm{b}}\right)$ values to signify binding affinities of the metal complexes towards DNA.

$$
[\mathrm{DNA}] /(\epsilon \mathrm{a}-\mathrm{Ef})=[\mathrm{DNA}] /(\mathrm{Eb}-\mathrm{Ef})+1 / \mathrm{Kb}(\mathrm{Eb}-\epsilon \mathrm{f})
$$

where $\mathrm{Kb}$ is intrinsic binding constant can be calculated from the slope $[1 /(\epsilon b-\epsilon f)]$ to intercept $\left[1 / K b(\epsilon b-\epsilon f)^{1}\right]$ ratio obtained by making a plot of $[D N A] /(\epsilon b-\epsilon f)$ against to $[D N A]$. Where $\epsilon a, C b$, and $\epsilon f$ are the apparent, bound metal complex and free metal extinction coefficients, respectively [16].

\subsubsection{Fluorescence quenching assay.}

In the line of collecting strong evidence for the mechanistic pathway of binding behavior of metal complexes with DNA, a competitive fluorescence inhibition experiment was carried out. Ethidium bromide is a strong classic intercalator with DNA base pairs and shows strong fluorescence intensity. The enhanced fluorescence intensity can be quenched with a metal complex (quencher), which interacts strongly with double-stranded DNA. The quenching mechanism proceeds either by replacing bound ethidium bromide or spoiling the secondary structure of DNA through groove binding or intercalative mode of binding [17].

The fluorescence quenching experiment was carried out by titrating a mixture of CTDNA $(125 \mu \mathrm{M})$ and ethidium bromide $(12.5 \mu \mathrm{M})$ against to incremental concentration metal complex $(0.0-60 \mu \mathrm{M})$. The fluorescence intensity can be monitored from $360 \mathrm{~nm}-700 \mathrm{~nm}$ for each successive addition of metal complex excited $\left(\lambda_{\text {ex }}\right)$ at $350 \mathrm{~nm}$ [18]. All the solutions were prepared by using Tris- $\mathrm{HCl}$ buffer $(5 \mathrm{mM}$ Tris- $\mathrm{HCl} / 50 \mathrm{mM} \mathrm{NaCl}$ buffer at $\mathrm{pH}-7.2)$, and triple distilled water was used throughout the experiment. The readings will be taken at room temperature. The data were used to calculate the quenching constant (Kq), a slope results by plotting $\frac{f o}{f}$ versus $[Q]$ gives the extent of quenching by the metal complexes using the SternVolmer equation $\frac{f o}{f}=K q[Q]+1$; $f o$ is the fluorescence emission intensity in the absence of quencher, $f$ is fluorescence intensity when binds with a quencher, $K q$ is the quenching constant, and $[Q]$ is quencher concentration. From the equation $\mathrm{K}_{\mathrm{EB}}[\mathrm{EB}]=\mathrm{K}_{\mathrm{app}}$ [complex], the apparent binding constant can be calculated.

\subsubsection{Viscosity measurement.}

Viscometry is one of the least ambiguous, flexible, and easy to carry out, which gives certain details regarding metal DNA binding interaction through the classical intercalative mode of binding by ethidium bromide [19]. The viscosity measurement was carried out by using Ostwald's Viscometer at a constant temperature bath $\left(26 \pm 1^{\circ} \mathrm{C}\right)$. A series sample solution was prepared with a step-wise concentration of metal complex $(0-60 \mu \mathrm{M})$ against a constant DNA concentration $(60 \mu \mathrm{M})$. A digital stopwatch was used to record flow time and repeated three times for each sample to get the mean value. The resultant data were plotted as $(\eta / \eta o)^{1 / 3}$ 
versus [complex]/[DNA], Where $\eta o$ and $\eta$ are the specific viscosity of nucleic acid with and without complexity, respectively, can be calculated from Eq. 2

$$
\eta=\mathrm{t}-\mathrm{to} / \mathrm{to}
$$

$t$ is the observed flow time of the DNA solution after each successive addition of the metal complex, and to is the flow time of DNA solution alone.

\subsubsection{DNA Cleavage studies with pBR322 plasmid DNA.}

DNA cleavage study accompanies the relaxation of supercoiled plasmid pBR322 DNA to nicked circular and linear conformation. The pBR322 DNA has faster mobility compared to nicked and linear conformation. A solution of pBR322 DNA in $0.5 \mathrm{mM}$ is prepared using Tris buffer(pH-7.2) and metal complexes $(50 \mu \mathrm{M})$ in DMSO. The cleavage assay was accomplished by the agarose gel electrophoretic method. The agarose gel medium is loaded with metal complex $(50 \mu \mathrm{M})$, pBR322 DNA $(0.5 \mathrm{mM})$, and $\mathrm{H}_{2} \mathrm{O}_{2}(100 \mu \mathrm{M})$ after incubation for $45 \mathrm{~min}$ at $37^{\circ} \mathrm{C}$. To this solution $0.25 \%$ bromophenol blue, $0.25 \%$ xylene cyanol and $30 \%$ glycerol were added along with $0.5 \mu \mathrm{g} / \mathrm{ml}$ ethidium bromide. The electrophoretic experiment was carried out at $10 \mathrm{~V} / \mathrm{cm}$ for $1 \mathrm{~h}$ in a TBE buffer [20]. The electrophoretic bands were visualized and captured under UV light. The band intensity after electrophoresis gives a quantitative measurement of cleavage efficiency.

\subsubsection{Pharmacology.}

Cytotoxicity is a measure of the ability of compound or complex to induce antiproliferation or cause cell death [21]. Most of the cytotoxicity measurement accompanies cellular necrosis [22]. To put more light on the cellular mechanism and type of cytotoxicity, including apoptosis and cellular necrosis, a systematic study panel based on dose and time dependence observation of toxic effects to the cell cycle and their reversibility is necessary. Cytotoxicity finds more significant towards concentration range for further in vitro testing to yield meaningful information on hematological and serum profile parameters. It is possible to compare the quantitative response of a single complex in several systems or several complexes in an individual system by establishing IC50 values (dose at which 50\% of the cell is affected).

The free ligand BMM and metal chelates of BMM were screened for their in vitro cytotoxic activity with various human cancer cell lines such as lung adenocarcinoma (A549), EAC (Ehrlich-Lettre Ascites), NIH-3T3 and breast adenocarcinoma (MCF-7). The complex C4 shows significant cytotoxic efficacy (IC50 value) against EAC cell line. Therefore, the investigation was extended further for hematological and serum profile analysis using reference protocol $[1,23]$.

\subsubsection{Cell culture and in vitro spectral assay.}

The human cancer cell lines A549, EAC, NIH-3T3 and MCF-7, cells were cultured and grown in DMEM (Dulbecco's Modified Eagle Media) with 10\% FBS (Foetal Bovine Serum) heat-inactivated supplement, with essential antibiotic and antimitotic solution supplied with $\mathrm{NaHCO}_{3}(0.37 \%)$ and incubated at $37^{\circ} \mathrm{C}$ with $98 \%$ humidified atmosphere containing $5 \% \mathrm{CO}_{2}$. The cytotoxic behavior of C1-C4 complexes with varying concentrations ( $0-100 \mu \mathrm{M}$ in DMSO) for $48 \mathrm{~h}$ and cytotoxic efficiency of BMM was examined, and IC50 values were calculated by trypan blue dye exclusion, MTT assay, and Lactate dehydrogenase (LDH) release assay as 
indicated by previous research method [24]. Each experiment was repeated three times with 5Fluorouracil as a positive control and analyzed.

\subsubsection{Cell proliferation using MTT assay.}

The novel ligand BMM and its complexes $(\mathrm{C} 1-\mathrm{C} 4)$ were tested for their cytotoxicity against four different types of human cancer cell lines viz., A549, EAC NIH-3T3, and MCF-7 and using a standard MTT reduction assay which described earlier [1, 3, 25]. In order to investigate cell viability, MTT assays were implemented. In this assay, a macro concentration of cells/ $200 \mu \mathrm{L} /$ well were seeded in 96 well plates and cultured in a complete DMEM medium containing $10 \%$ FBS. Cells were incubated with different concentrations $(5,10,15,20,25 \mu \mathrm{M})$ of C1-C4 scanned individually for $24 \mathrm{hrs}$. Under the same condition, cells with $0.1 \%$ DMSO as vehicle control and 5-fluorouracil as positive control were also cultivated separately. Once the $48 \mathrm{~h}$ incubation period was over, the old medium from treated cells was replaced with fresh medium, and further cells were incorporated with MTT reagent $(5 \mu \mathrm{g} / \mathrm{mL}$ in PBS) in each well for 2-3 hours at $37^{\circ} \mathrm{C}$. After the incubation period, $100 \mu \mathrm{L}$ of DMSO was added to each well, followed by carefully removing the supernatant layer. The yellow tetrazolium salt (MTT) is reduced to form insoluble purple formazan crystals in metabolically active cells dissolved in DMSO. The color was measured quantitatively using a spectrophotometric method monitored at $560 \mathrm{~nm}$ wavelength on a microlitre plate reader.

\subsubsection{Spectral probe for cancer cell adhesion.}

To monitor the cell adhesion properties of cancer cells, a spectral probe was carried out with cytoselect 24-well cell adhesion. A triplicate concentration of C2 and C4 was made in accordance with IC50 values, tested against various cancer cell lines such as EAC, A549, NIH3T3, and MCF-7. To each pre-warmed adhesion well plate, cancer cells ( $\left.10^{6} \mathrm{cells} / \mathrm{mL}\right)$ are suspended in free serum medium was introduced and incubated for one hour in an incubator saturated with $\mathrm{CO}_{2}$ and followed as for the literature protocol $[3,26]$. After the incubation period, wells are air-dried and stained, then extracted (adhered cells) using an extraction medium. The extracted adhered cells were subjected to spectral observation in which the absorbance was made at $560 \mathrm{~nm}$ in a microtiter reader.

\subsubsection{Spectral measurement of cancer cell migration.}

An absorbance experiment was performed with a cytoselect 24- well cell migration probe on EAC, A549, NIH3T3, and MCF-7 cancer cell lines. To induce quantitatively, the concentration of $\mathrm{C} 2$ and $\mathrm{C} 4$ was made in triplicate as far IC50 values were screened on EAC, A549, NIH3T3, and MCF-7 cancer cell lines. The test complexes were injected with a solution containing $10 \%$ fetal bovine serum in the lower well of the migration plate along with cell suspension containing $100 \mu \mathrm{L}$ of $0.5-1.0 \times 10^{6}$ cells / $\mathrm{mL}$ is also introduced. The absorbance of each sample was recorded at $560 \mathrm{~nm}$ after incubated for $8 \mathrm{~h}$ at $37^{\circ} \mathrm{C}$ in a $\mathrm{CO}_{2}$ enriched incubator [1, 27]. 
2.3.5. In vivo toxicity.

\subsubsection{Toxicity study panel.}

The complexes $\mathrm{C} 2$ and $\mathrm{C} 4$ were suspended in $0.25 \%$ carboxymethylcellulose and intraperitoneally administered to randomly divided different groups of mice(males) with a different doses of complexes $\mathrm{C} 2$ and $\mathrm{C} 4(0.025,0.05,0.075,0.1,0.125 \mathrm{~g} / 0.1 \mathrm{~kg})$. The mice were carefully monitored for $72 \mathrm{~h}$ for their toxicity and mortality indication, and LD50 was calculated as for the reference method $[1,28]$.

\subsubsection{Chronic Toxicity Studies.}

In order to allocate for control and test groups, a total of 30 male and 30 female Swiss albino mice were taken randomly. To affect the feasibility of administration, the complexes were mixed with drinking water due to the long treatment duration with a dose close to $1 / 10^{\text {th }}$ of the LD50. The treatment was continued up to 12 weeks and then monitored for all external indications of body weight changes, toxicity, and mortality. Ten male and ten female rats were utilized in each group, having one control and two treated groups. The pregnancy outcomes were examined after one group of female rats allowed mat with the treated male. The urine sample was collected 1 or 2 days before completion of treatment. The treated rats have fasted for $12 \mathrm{~h}$, and then ether was injected to induce an anesthetic condition. The blood samples were collected and centrifuged for $10 \mathrm{~min}$ at 3000rpm [29, 30]. The biochemical parameters were analyzed from the plasma stored at $-20^{\circ} \mathrm{C}$, after removing vital organs, which will be weighed and subjected to further investigation on toxicity signs.

\subsubsection{Hematological and serum profile analysis.}

In order to investigate hematological and serum profile parameters, non-centrifuged blood was collected. The blood samples from the treated mice were used to determine hematological parameters such as WBC and RBC count, platelets, hemoglobin, lymphocytes, and neutrophils. Further, a colorimetric method is followed to determine the biochemical parameters or for serum profile analysis (SGPT, SGOT, ALP, bilirubin, and lipid profile) in plasma [30].

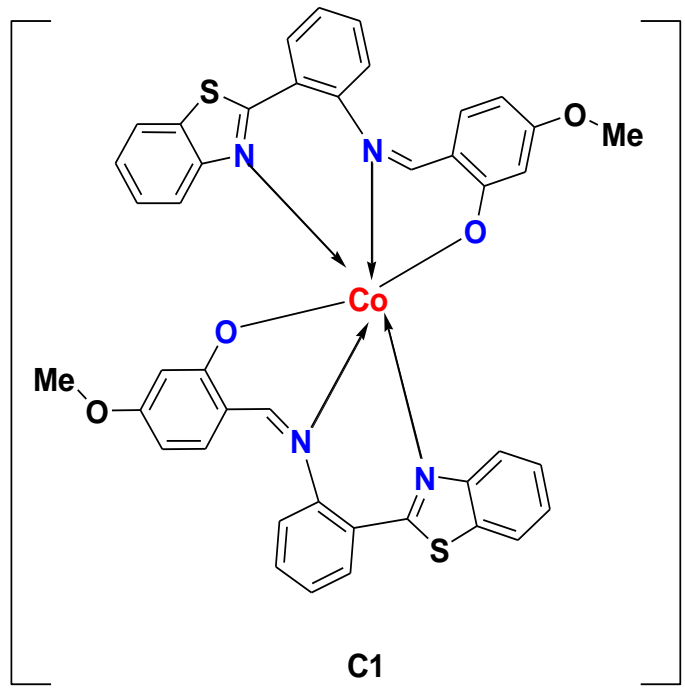

$\mathrm{Cl}$

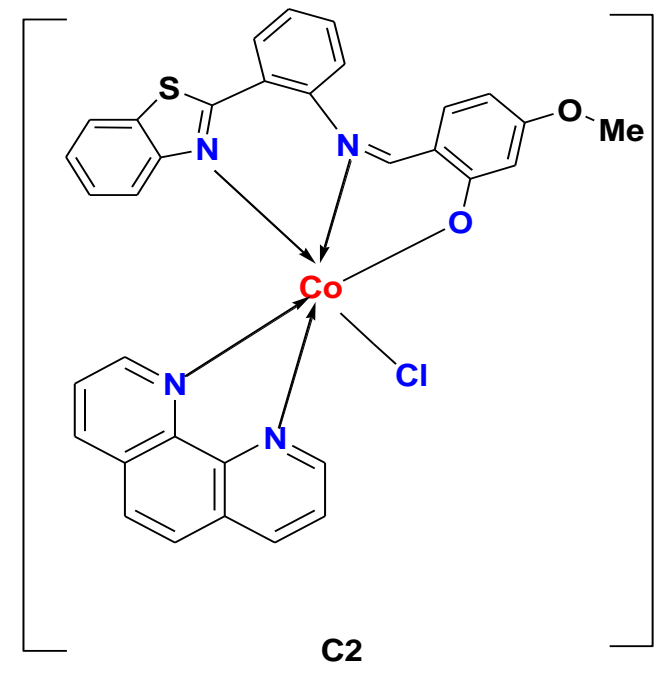

Cl 


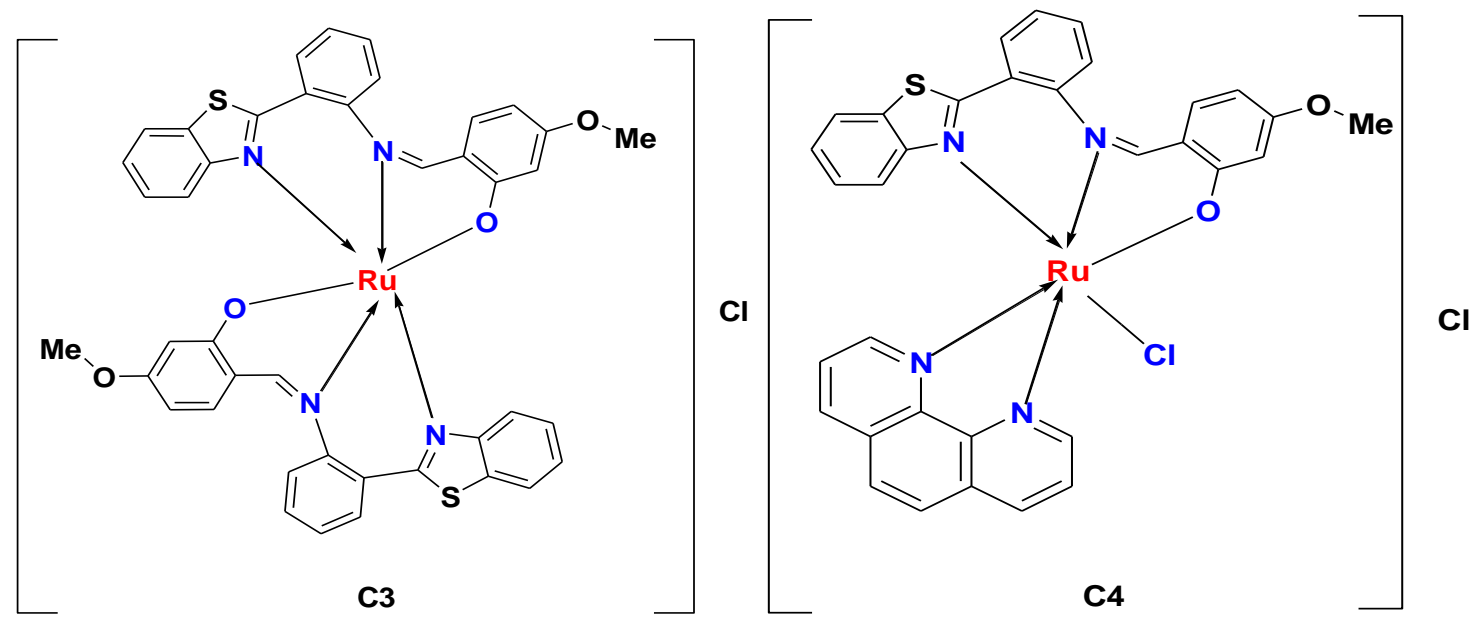

Figure 1. Proposed structures of complexes $(\mathrm{C} 1-\mathrm{C} 4)$

\section{Results and Discussion}

\subsection{Physico-chemical characterization.}

The ligand and its $\mathrm{Co}(\mathrm{III})$ and $\mathrm{Ru}(\mathrm{III})$ complexes were stable at room temperature without undergoing any kind of decomposition. They are slightly soluble in ethanol but makes clear solution with DMSO and DMF. The physical parameters of the synthesized ligand and its metal complexes are displayed in Table 1 . The elemental analysis results are in fairly agree with the calculated data. The metal contents of the complex were determined by following previous literature methods [31].

The $\mathrm{Co}(\mathrm{III})$ and $\mathrm{Ru}(\mathrm{III})$ complexes were subjected to molar conductivity measurement using $10^{-3} \mathrm{M}$ solution in $\mathrm{DMSO}$ at $25^{\circ} \mathrm{C}$. All the complexes show appreciable molar conductance indicating a 1:1 electrolytic nature and consistent with the formula $\left[\mathrm{M}(\mathrm{BMM})_{2}\right] \mathrm{Cl}$, $[\mathrm{M}(\mathrm{BMM})(\mathrm{Ph}) \mathrm{Cl}] \mathrm{Cl}$ of metal complexes. The observed magnetic moment is less than the calculated one because of the asymmetry around ligand environment, and as we move from $\mathrm{C} 1$ to $\mathrm{C} 2$ and $\mathrm{C} 3$ to $\mathrm{C} 4$, the magnetic moment decreases as it increases the asymmetric ligand parameter. The $\mathrm{Co}(\mathrm{III})$ and $\mathrm{Ru}(\mathrm{III})$ complex shows the magnetic moment in the range 1.653.92BM confirms the +3 oxidation state for both metals and agrees in accordance with octahedral geometry.

Table 1. Physical characterization- Elemental analysis, molar conductance, and magnetic susceptibility data of

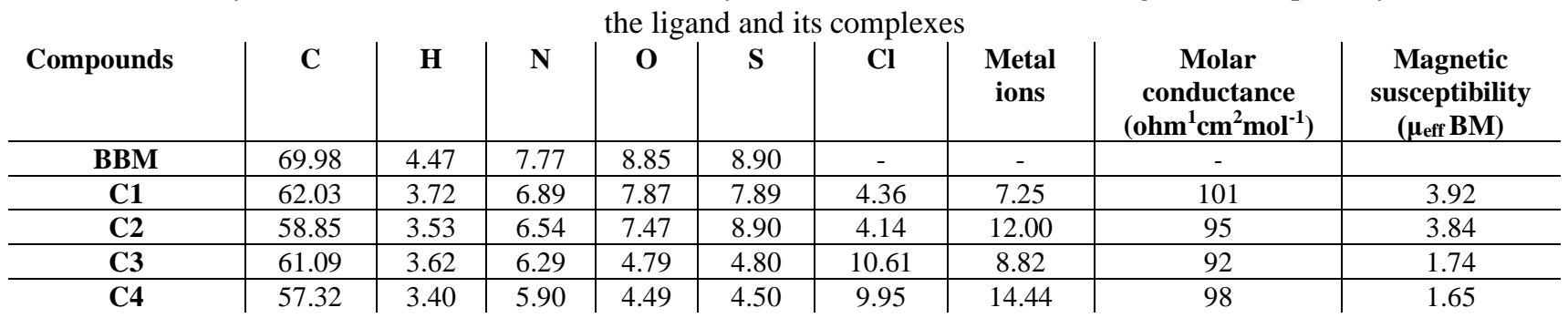

\subsection{Electronic absorption spectra.}

The electronic spectral probe indicates the basic features of electronic absorption corresponding to different transitions in the Uv-visible region. The electronic spectra of all the complexes were recorded by running DMSO as blank at room temperature. The electronic spectra of ligand characterized by the presence of two main absorption bands between the range 260-258 and $310-325 \mathrm{~nm}$ attributed to $\pi-\pi^{*}$ transition aroused mainly from the phenolic 
chromophore and $n-\pi *$ transitions located on thiazole moiety [32]. In the metal complexes, CT bands are observed relatively at $410-437 \mathrm{~nm}$, and the band at $510-554 \mathrm{~nm}$ reflects the $\mathrm{d}-\mathrm{d}$ band. A slight change in the absorption is observed upon complexation with Co(III) metal ions. This may be due to the contribution of the phenoxy oxygen atom towards the central metal atom. In the preceding electronic absorption, a band appears in the range of 380-430nm attributed to n$\pi^{*}$ transition involving azomethine moiety containing $\mathrm{C}=\mathrm{N}$ chromophore (Fig. 2). In the way of coordination, a slight shift is observed in $n-\pi^{*}$ transition upon chelation with metal ion indicates subsequent involvement of nitrogen of azomethine group [33].

In most $\mathrm{Ru}$ (III) complexes, charge transfer of the type L $\pi y-\mathrm{T} 2 \mathrm{~g}$ is prominent in the lower region due to the d-d transition [34]. All the bands that emerge in the visible region are charged transfer transitions of octahedral Ru(III) complexes. In the electronic absorption of the ESR active $\mathrm{Ru}$ (III) complex spectrum, a weak band observed at $480 \mathrm{~nm}$ reflects d-d transition and another band at 345-390nm assigned to CT band, which further confirms octahedral environment to $\mathrm{Ru}$ complex.

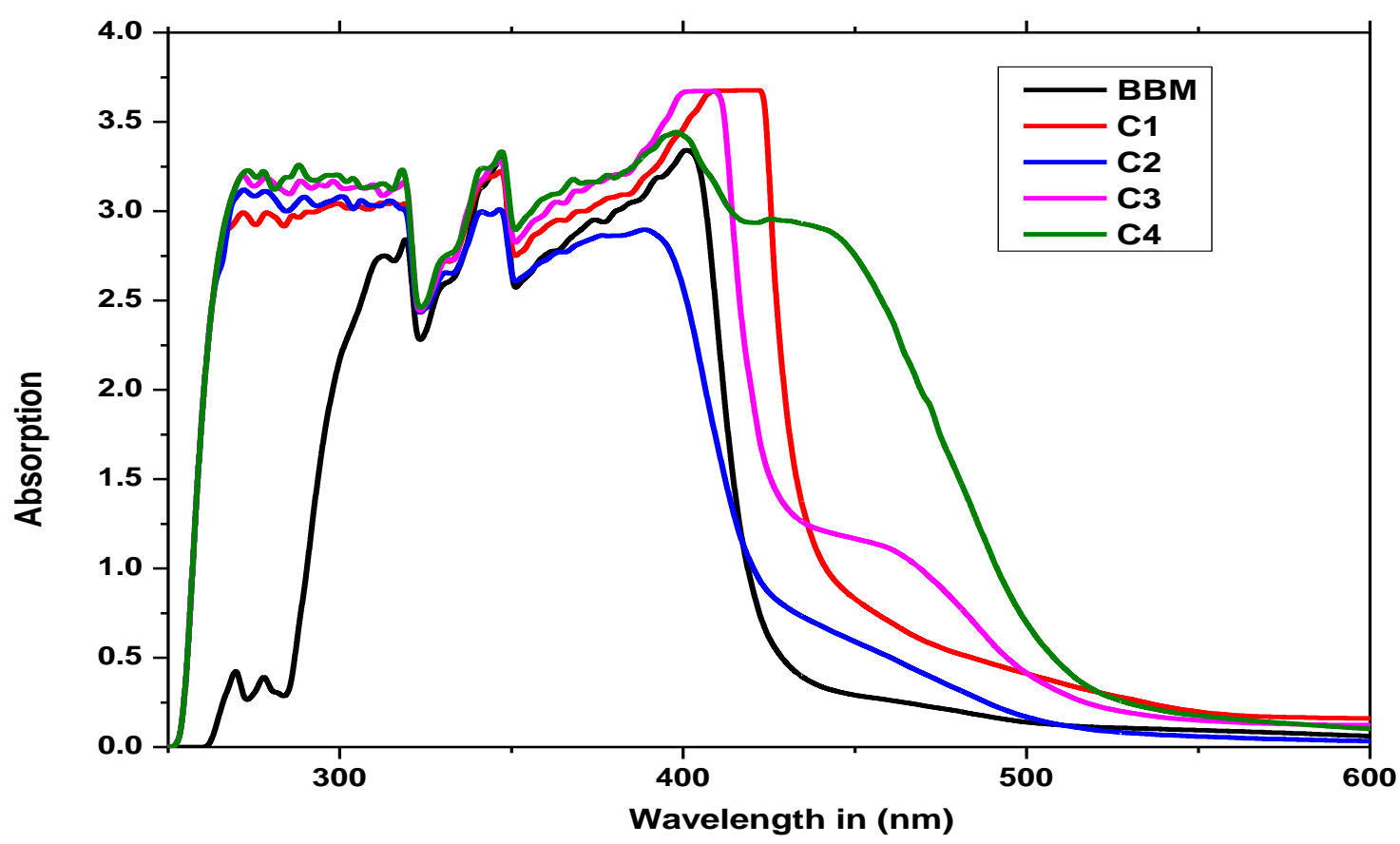

Figure 2. UV-Visible spectra of BMM and C1-C4 complexes in DMSO solution.

\subsection{IR spectral studies.}

IR spectral probe was used for a preliminary investigation for identifying the involvement of azomethine group in the chelation with $\mathrm{Co}$ (III) and $\mathrm{Ru}$ (III) metal ions. The IR spectrum of the metal complex displayed important evidence with an additional band at $1610 \mathrm{~cm}^{-1}$, and $1020 \mathrm{~cm}^{-1}$ characteristic of $v_{\mathrm{C}=\mathrm{N}}$ and $v_{\mathrm{CH}=\mathrm{N}}$ of the azomethine group confirms basic skeleton of Imine base (Fig. 3). The chelation of Imine base with $\mathrm{Co}$ (III) and $\mathrm{Ru}$ (III) leads to a higher shift in stretching vibration $v_{\mathrm{C}=\mathrm{N}}$ assigned to azomethine group, and significant alteration is observed in stretching frequency of $\mathrm{C}-\mathrm{O}$ bond indicates the involvement of hydroxyl group for complexation [35]. No absorption peaks are observed around 3400$3600 \mathrm{~cm}^{-1}$, indicating that the complex is free from water molecules within the coordination sphere and lattice. 


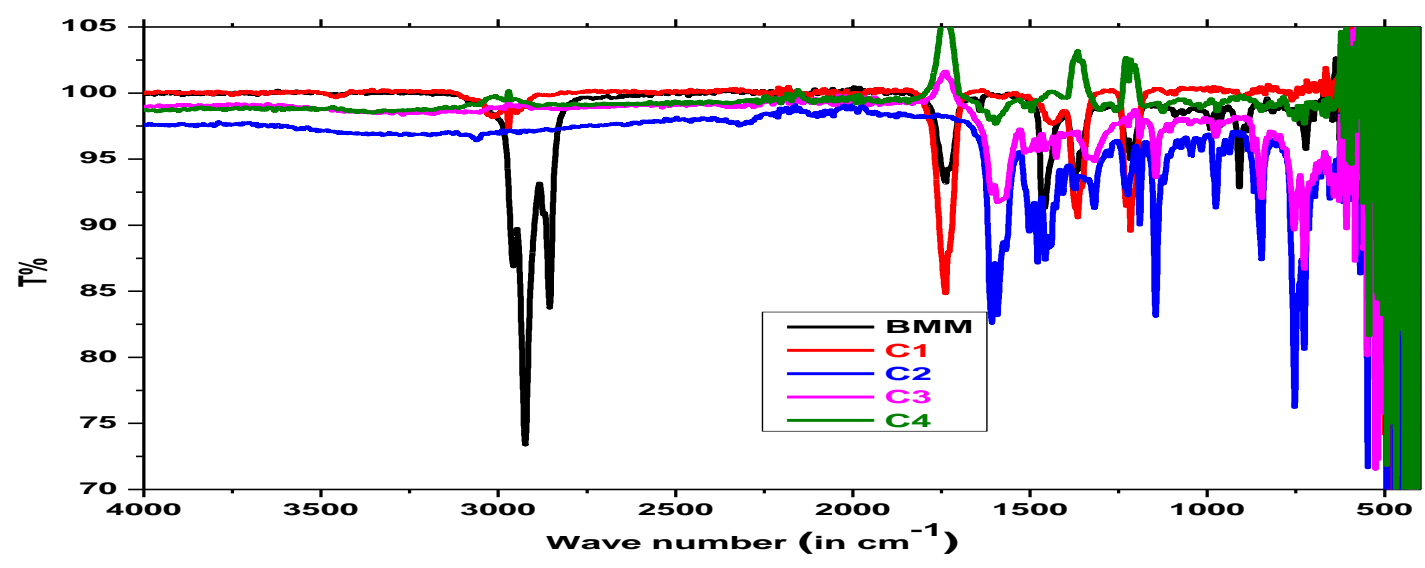

Figure 3. FT-IR spectra of BMM and C1-C4.

\subsection{Thermogravimetric analysis.}

Thermal analysis is ideal for measuring the metal complex's thermal behavior, thermal stability, and phase transition. TGA data have been taken under a dynamic nitrogen atmosphere with temperatures ranging from $20-800^{\circ} \mathrm{C}$ (Fig. 4). The investigated $\mathrm{Co}$ (III) and $\mathrm{Ru}$ (III) complexes were found to have higher air and thermal stability, as indicated from their conductivity measurement taken after allowing at room temperature for a long time. The TG analytical and DT analytical plot of C3 and C4 as depicted in Figure 4. The thermogram of C3 and $\mathrm{C} 4$ consisting three well-resolved decomposition deflection peaks, respectively. The first decomposition deflection point surfaced above $300^{\circ} \mathrm{C}$ indicates that the investigated complexes are completely free from hydration within and outside the coordination sphere and agree with FT-IR spectral data [38].

As in the case of $\left[\mathrm{Ru}(\mathrm{BMM})_{2}\right] \mathrm{Cl}, \mathrm{C} 3$, the first two decomposition peaks surfaced at $295{ }^{\circ} \mathrm{C}-310^{\circ} \mathrm{C}$ with a net weight loss of $33.06 \%$ and $315^{\circ} \mathrm{C}-400{ }^{\circ} \mathrm{C}$ with a net weight loss of $21.77 \%$. The third infection point occurs at $420{ }^{\circ} \mathrm{C}-650{ }^{\circ} \mathrm{C}$ with a net weight loss of $31.54 \%$; above this temperature, no variation in weight loss indicates the existence of $\mathrm{RuO}_{2}$ as a stable solid.
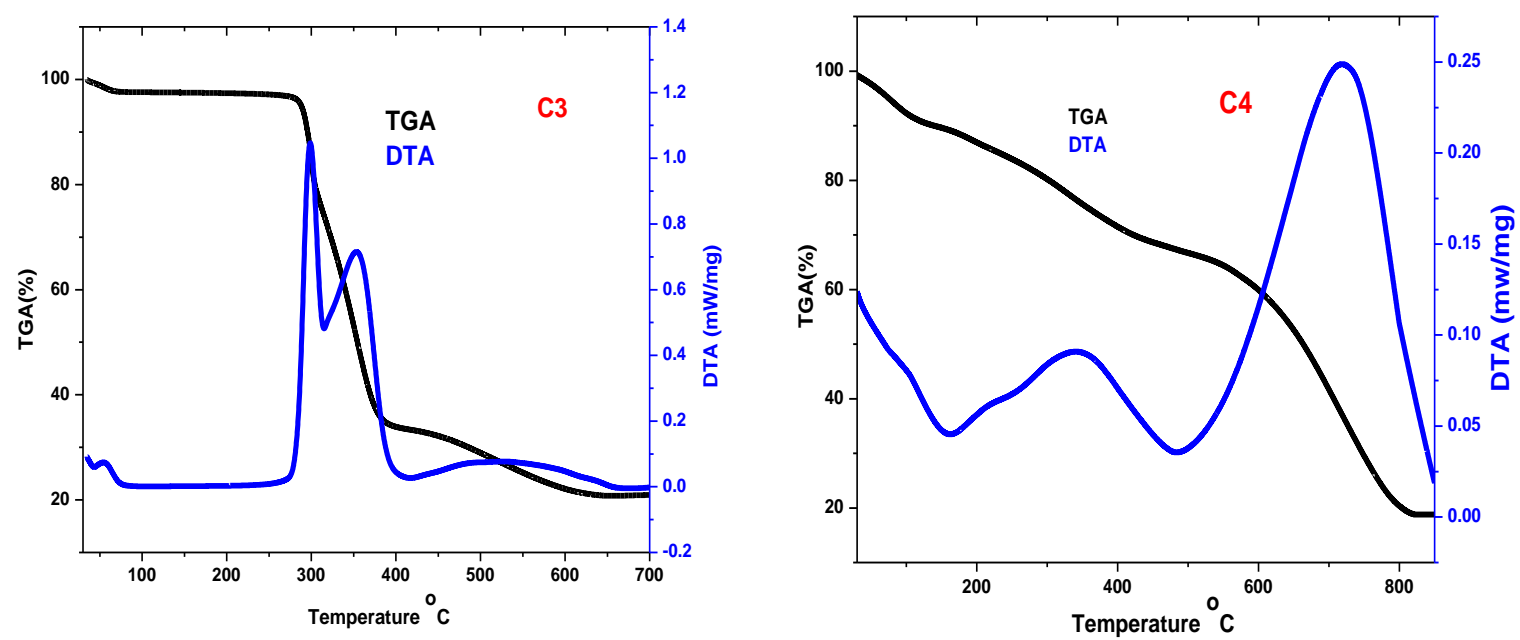

Figure 4. TGA and DTA for C3 and C4.

As in the complex $[\mathrm{Ru}(\mathrm{BMM})(\mathrm{Ph})] \mathrm{Cl}, \mathrm{C} 4$, the first decomposition peaks originates at a relatively lower temperature at $95^{\circ} \mathrm{C}-180{ }^{\circ} \mathrm{C}$ with a net weight loss of $13.06 \%$ due to the loss of coordinated $\mathrm{Cl}$ atom and at $455^{\circ} \mathrm{C}-450{ }^{\circ} \mathrm{C}$ with a net weight loss of $41.77 \%$ may be due to 
the loss of phenanthroline moiety. The third infection occurs at $455^{\circ} \mathrm{C}-850{ }^{\circ} \mathrm{C}$ with a net weight loss of $27.42 \%$; above this temperature, a constant weight is recorded, indicating the existence of $\mathrm{RuO}_{2}$ as a thermally stable solid.

\subsection{Mass spectra.}

Mass spectral analyses were recorded at room temperature via electron spray ionization, and the mass spectral data were used to distinguish the different stoichiometric compositions of complexes. The spectra of $\left[\mathrm{Co}(\mathrm{BMM})_{2} \mathrm{Cl}\right] \mathbf{C 1}$ showed molecular ion peak at $777 \mathrm{~m} / \mathrm{z}$ and $\mathrm{M}+1$ peak at $778 \mathrm{~m} / \mathrm{z},[\mathrm{Co}(\mathrm{BMM}) \mathrm{PhCl}] \mathrm{C2}$ shows $\mathrm{M}+$ peak at $684.9787 \mathrm{~m} / \mathrm{z},[\mathrm{Ru}(\mathrm{BMM}) \mathrm{Cl})$ C3 shows $\mathrm{M}+$ peak at $855 \mathrm{~m} / \mathrm{z}$ and $\mathrm{M}+2$ peak $857 \mathrm{~m} / \mathrm{z}$ and $[\mathrm{Ru}(\mathrm{BMM}) \mathrm{PhCl}] \mathrm{C} 4$ gives $\mathrm{M}+$ peak at 691.1321. All the spectral data were satisfactorily coinciding with calculated mass data.

\subsection{Paramagnetic spectra.}

The EPR spectrum of solid $\mathrm{Ru}(\mathrm{III})$ complexes, $\mathrm{C} 3$ was recorded at room temperature $(300 \mathrm{~K})$, using X-band frequency display a classical isotropic single band with no hyperfine interaction suggests that unpaired electron spends no time in the vicinity of Ru nucleus or due to the extensive delocalization. The obtained $g$ value is consistent with a low spin Ruthenium complex having $\mathrm{d}^{5}\left(\mathrm{t}_{2 \mathrm{~g}}{ }^{5}\right)$ system with $\mathrm{S}=1 / 2$. The shape of EPR spectrum reveals an octahedral chemical environment around the Ru nucleus. The $g$ value obtained from EPR spectra with $g_{x}$ $=\mathrm{g}_{\mathrm{y}} \neq \mathrm{g}_{\mathrm{z}}, \mathrm{gx}=\mathrm{gy}=1.84, \mathrm{gz}=2.38$ indicates tetragonal distortion from octahedral geometry for the EPR investigated $\mathrm{C} 3\left[\mathrm{Ru}(\mathrm{BMM})_{2} \mathrm{Cl}\right]$ complex (Fig. 5).

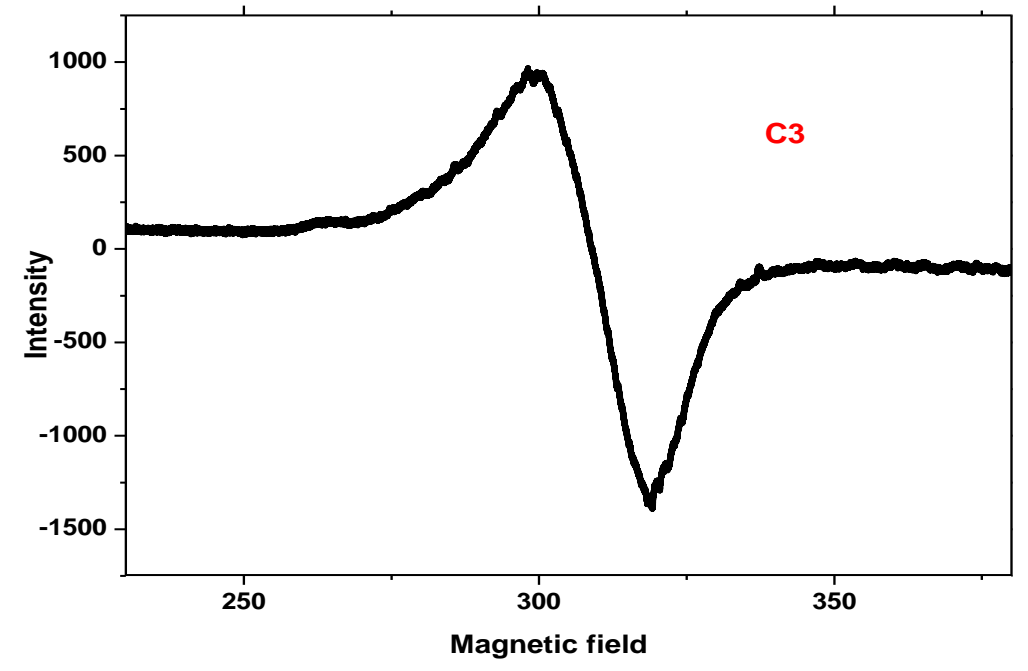

Figure 5. EPR Spectrum of Ru complex C3.

\subsection{Powdered X-ray studies.}

In the line of investigation regarding the crystalline or amorphous nature of solid metal complex, the powder sample of $\mathrm{Co}$ (III) complexes were scanned for $2 \theta$ ranging from $10^{\circ}$ to $90^{\circ}$ on a PANanalytical X-ray diffractometer. The powder X-ray analysis was carried as it was difficult to isolate a single crystal from the solvents. The powdered $\mathrm{X}$-ray data is free from well-defined peaks, indicating that the majority contribution to the solid-state is from the amorphous part depicted below. The diffractogram (Fig. 6) of Co(III) reflects powder X-ray diffraction patterns of C3 and C4. Debye Scherrer's equation is used in order to calculate the crystallite size as follows 


$$
\mathrm{D}=0.9 \lambda / \beta \cos \theta
$$

where $\lambda$ is the wavelength $\left(1.54 \mathrm{~A}^{\circ}\right)$ at which diffraction takes place and multiplies by shaper factor $0.9, \theta$ is the angle of Bragg's diffraction, and $\beta$ is the full width at half maximum (FWHM). The average grain size of metal complexes was experimentally found to be 45.42 (C3), $32.15 \mathrm{~nm}$ (C4) [39].
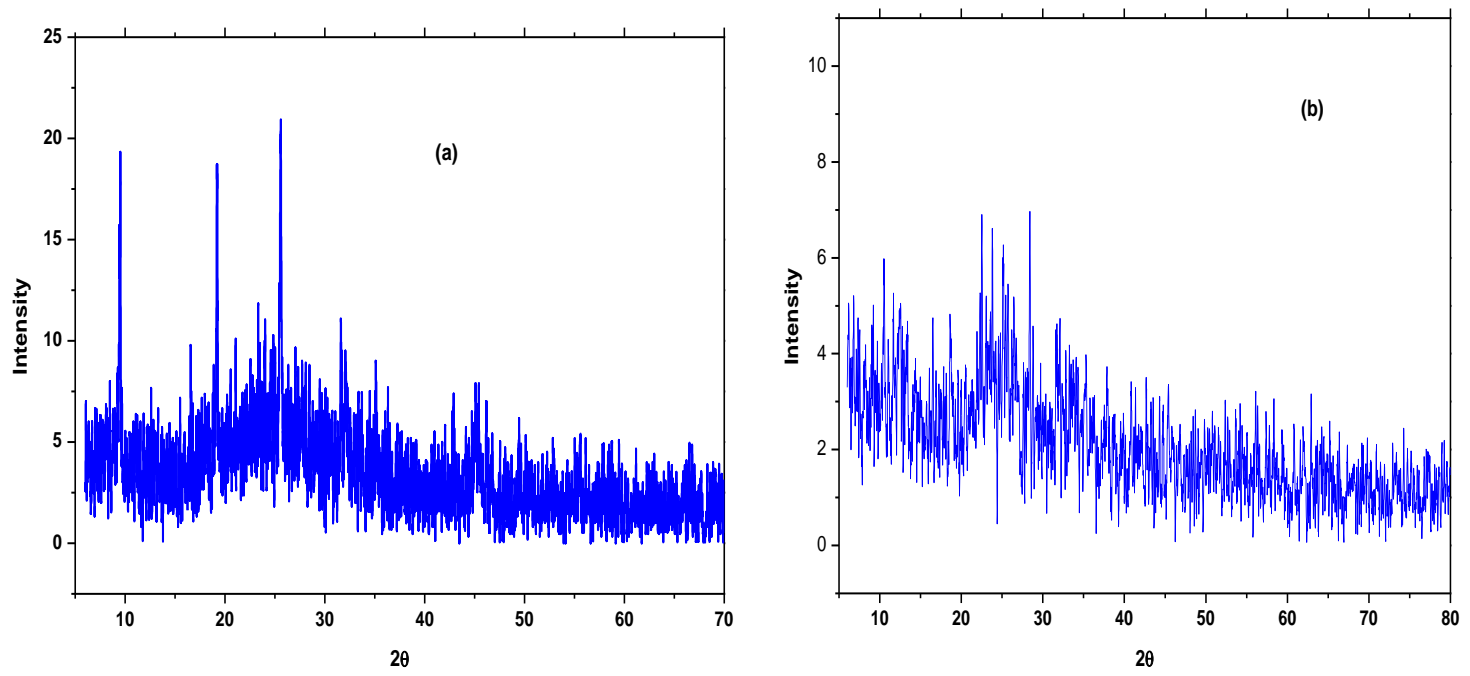

Figure 6. Powder XRD of complexes (a) C3 and (b) C4.

\subsection{Biologic evaluation.}

\subsubsection{In vitro antimicrobial assay.}

The results displayed that the complex $\mathrm{C} 1$ and $\mathrm{C} 3$ showed moderate activity with zone inhibition of $15 \mathrm{~mm}$ at a concentration of $50 \mu \mathrm{g} / \mathrm{L}$, and the complex $\mathrm{C} 2$ and $\mathrm{C} 4$ emerged as an efficient antimicrobial agent with zone inhibition of $25 \mathrm{~mm}$ at a concentration of $50 \mu \mathrm{g} / \mathrm{L}$ (Fig. 7 and Table 2).

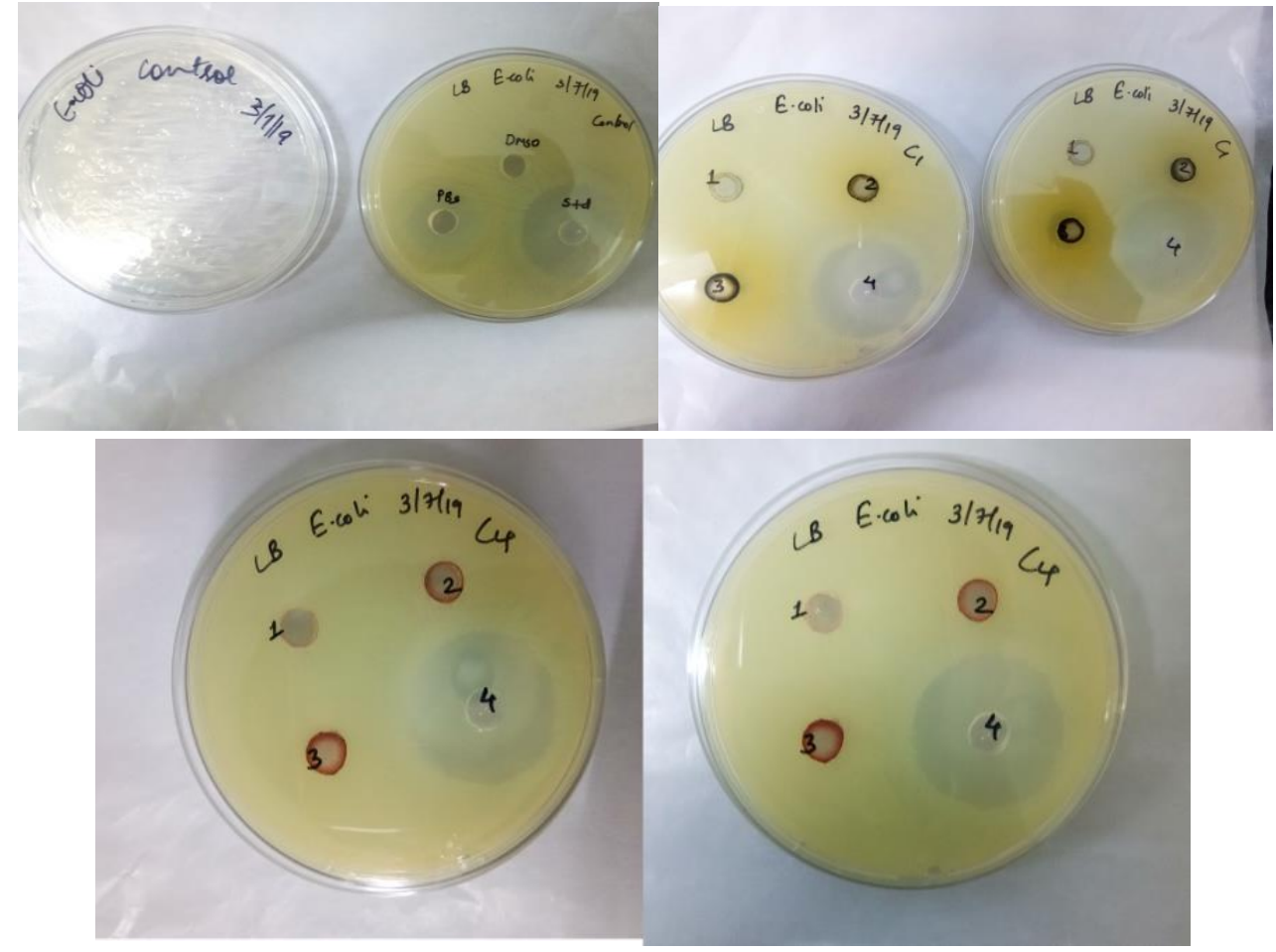

Figure 7. The bactericidal activity of $\mathrm{C} 2$ and $\mathrm{C} 4$ on E. coli. 
The Imine base ligand 2-((E)-(2-(benzo[d]thiazol-2-yl)phenylimino)methyl)-5methoxyphenol is actually consisting of electron-donating groups such as methoxy on aryl ring along with metal chelation are solely responsible for the moderate antimicrobial activity against E. coli and $P$. aeruginosa for the complex $\mathrm{C} 1$ and $\mathrm{C} 3$ [40]. For the complexes $\mathrm{C} 2$ and $\mathrm{C} 4$, the enhanced antibacterial activity is attributed to the presence of 1,10 phenanthroline ligand, which induces more planarity, flexibility, and lipophilicity to the complex [41]. This will facilitate the penetration of the complex into the cell membrane, which is mainly composed of the lipid-protein layer. On complexation with a metal ion, the polarity of metal ion diminishes as it shares its positive charge density towards ligand due to the ligand-metal orbital overlapping and the presence of co-ligand 1,10 phenanthroline increases the delocalization of $\pi$-electrons over the whole chelate ring and also enhances the lipophilicity of the metal complexes in $\mathrm{C} 2$ and $\mathrm{C} 4$ [42]. This aspect makes the point for the potent activity for significant antimicrobial activity of complex $\mathrm{C} 2$ and $\mathrm{C} 4$.

Table 2. Results of antimicrobial activity of ligand and C1-C4.

\begin{tabular}{c|c|c|c|c} 
& \multicolumn{4}{|c}{ Zone of inhibition (in "mm") } \\
\hline \multirow{2}{*}{ Compound } & \multicolumn{2}{|c|}{ Gram-positive bacteria } & \multicolumn{2}{c}{ Gram-negative bacteria } \\
& B. subtilis & S. aureus & E. coli & P. aeroginosa \\
\hline BMM & 15 & 17 & 15 & 16 \\
\hline C1 & 13 & 15 & 12 & 13 \\
\hline C2 & 21 & 21 & 19 & 17 \\
\hline C3 & 20 & 14 & 18 & 25 \\
\hline C4 & 23 & 21 & 22 & $\mathbf{3 2}$
\end{tabular}

3.8.2. DNA binding studies.

\subsubsection{Electronic absorption titration:}

Electronic spectral studies give more light on the mode and mechanistic pathways of interaction by the metal complexes $\mathrm{C} 1$ to $\mathrm{C} 4$ with CT DNA. The important spectral feature with respect to DNA and its helical structure is Hypochromism results from conformational changes and Hyperchromism attributed to structural damage of DNA [43]. The spectral data were recorded in the presence and absence of DNA that shows two Uv-bands near 290nm and $370 \mathrm{~nm}$ corresponding to $\pi-\pi^{*}$ and ligand to metal charge transfer transition (LMCT) [44], respectively. Upon incremental addition of CT-DNA $(0.0-25 \mu \mathrm{M})$ against a fixed concentration $(30 \mu \mathrm{M})$ of complex $\mathrm{C} 1$ to $\mathrm{C} 4$, the said absorption bands show hypochromic shift with a slight decrease in the wavelength of absorption (blue shift). The downward shift in the intensity of the spectra clearly indicates that the metal complexes perturb the helical structure with slightly affecting the conformation of CT-DNA through non-covalent intercalative binding and electrostatic mode [45]. But the non-intercalative mode of binding cannot be ruled out completely as of only a slight change in absorption bands in $\mathrm{C} 3$ and $\mathrm{C} 4$ to a certain extent. The observed hypochromic effect assures mainly groove mode of binding due to the strong $\pi-\pi$ stacking interaction between the DNA base pairs and an aromatic moiety of the metal complex. The degree of groove binding correlates with the magnitude of the binding constant of the metal complex. The binding constant $\left(\mathrm{K}_{\mathrm{b}}\right)$ was determined by recording changes in absorbance upon concomitant addition of CT-DNA using equation (1) [46].

The intrinsic binding constant of the metal complexes was calculated as $9.5 \times 10^{3} \mathrm{M}^{-1}$, $2.3 \times 10^{4} \mathrm{M}^{-1}, 5.6 \times 10^{3} \mathrm{M}^{-1}$, and $2.7 \times 10^{4} \mathrm{M}^{-1}$ corresponding to the complex $\mathrm{C} 1, \mathrm{C} 2, \mathrm{C} 3$, and $\mathrm{C} 4$. 
In comparison with classic DNA intercalators such as ethidium bromide (EB), methylene blue (MB), and acridine orange (AO), the complex $\mathrm{C} 2$ and $\mathrm{C} 4$ complexes show strong nonintercalative or groove mode of binding with DNA (Fig. 8). These can be attributed to the presence of planar phenanthroline ligand enhancing surface binding interaction with DNA, and the binding efficiency follows the order $\mathrm{C} 4>\mathrm{C} 2>\mathrm{C} 1>\mathrm{C} 3$.
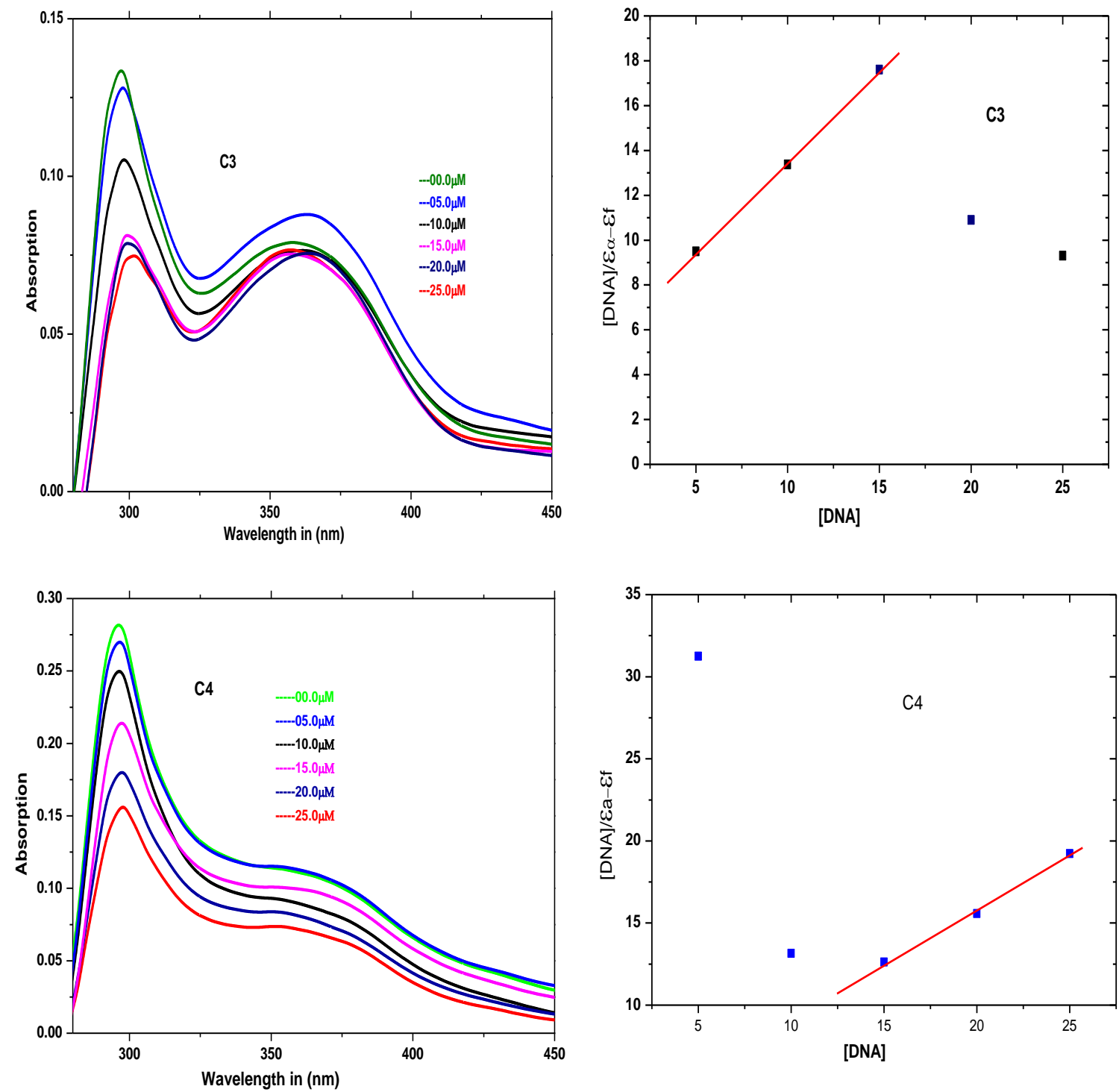

Figure 8. The electronic absorption spectra of metal complexes C3 (left) and C4 (right) in the presence and

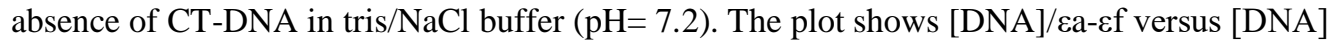

\subsubsection{Fluorescence quenching assay.}

A sensitive competitive fluorescence quencher has been introduced into the spectral probe to prove different modes of interaction by the metal complex with CT-DNA. Owing to the efficiency of the quencher, if the metal complex can compete firmly with ethidium bromide, which is bound to DNA, measures the magnitude of the quenching strength [47]. A concomitant decrease in the fluorescence intensity was observed at $282 \mathrm{~nm}$ along with a slight red shift upon gradual increment in the metal complex, as depicted in Figure 9. This confirms that EB molecules are displaced partially or fully from their respective site in DNA by the metal complex through groove mechanism (planar, electrostatic, and $\mathrm{H}$ - bonded interaction) [48]. The intercalating efficacy $\mathrm{Kq}$ of the metal complex with DNA was determined using the classical Stern-Volmer equation $\frac{f o}{f}=K q[Q]+1$ from the slope by the plotting of $\frac{f o}{f}$ versus $[Q]$. 
The Stern-Volmer constant $\left(\mathrm{K}_{\mathrm{Sv}}=\mathrm{K}_{\mathrm{q}}\right)$ is found to be for the complex $\mathrm{C} 16.5 \times 10^{3} \mathrm{M}^{-1}, \mathrm{C} 2$ $2.1 \times 10^{4} \mathrm{M}^{-1}$, C3 $7.4 \times 10^{3} \mathrm{M}^{-1}$ and $\mathrm{C} 42.6 \times 10^{4} \mathrm{M}^{-1}$, respectively. These data suggest that the complex $\mathrm{C} 2$ and $\mathrm{C} 4$ shows marked affinity towards DNA compared to other complexes. The apparent binding constant (Kapp) calculated from the relation $\mathrm{K}_{\mathrm{EB}}[\mathrm{EB}]=\mathrm{K}_{\mathrm{app}}$ [complex] found to be in the range of $2.6 \times 10^{4} \mathrm{M}^{-1}$ indicates that the complex $\mathrm{C} 4$ displays a greater amount of ethidium bromide in EB-CT DNA adduct and is consistent with the previous conclusions.
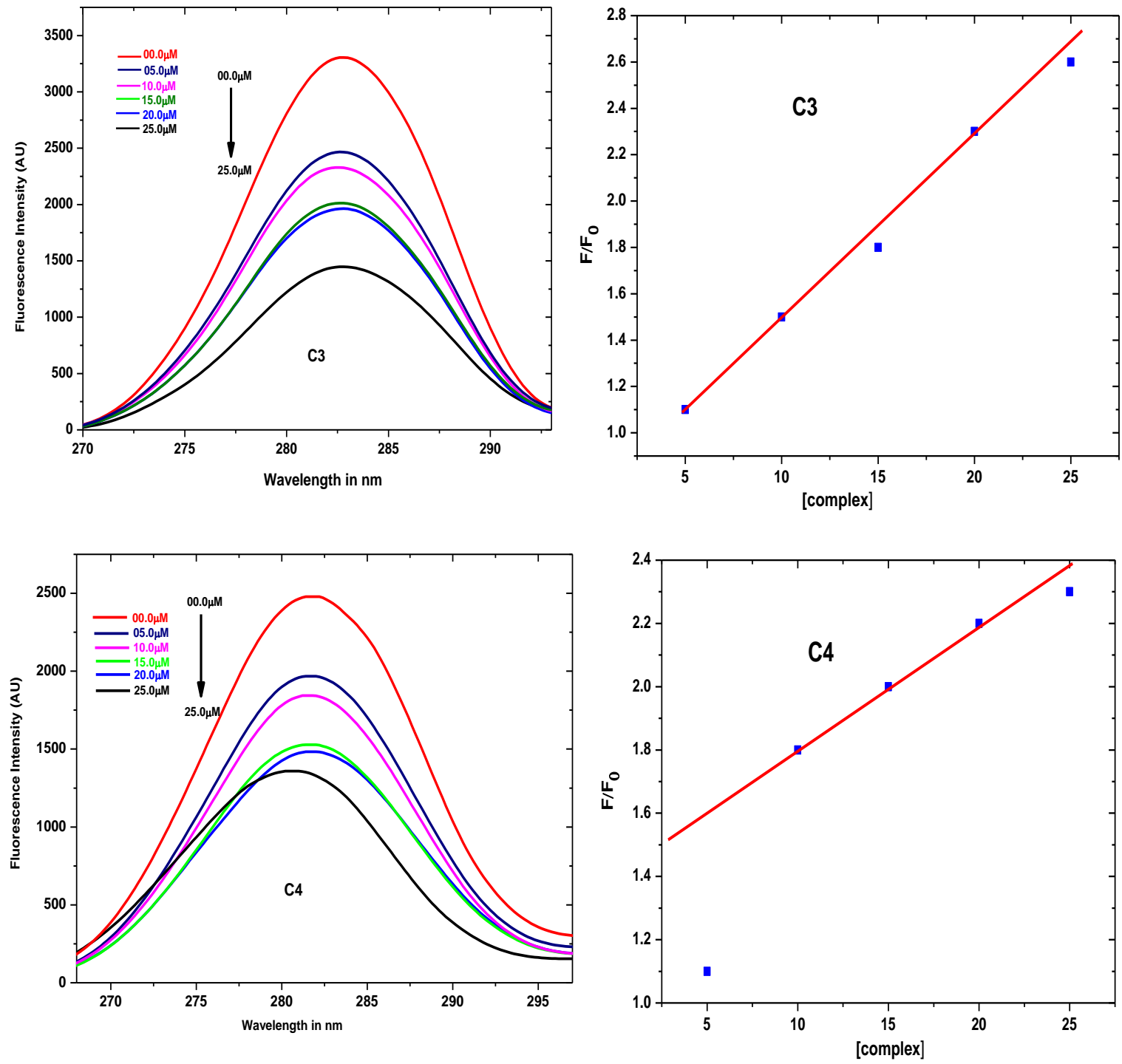

Figure 9. Quenching spectra of EtBr-DNA in the presence of metal complexes $\mathrm{C} 2$ and $\mathrm{C} 4$ at the concentration $0-25 \mu \mathrm{M}$ in tris/ $\mathrm{NaCl}$ buffer $(\mathrm{pH}=7.2)$. The plot indicates the fit of fluorescence intensity versus [complex].

\subsubsection{DNA binding assay in terms of Viscosity measurement.}

Upon binding with metal complexes, DNA changes its structure, conformation, and length of the double helix, which surely reflects a change in the viscosity. Therefore, the measurement of viscosity of DNA solution before and after interaction with metal complex makes a convenient, most critical, and less ambiguous method to interpret binding characteristics in the absence of crystallographic data. The intercalative mode of the binding shows a hike in the viscosity due to an increase in the DNA base pair separation at the point of DNA complex intersection, which lengthens DNA helix as in the case of ethidium bromide. On the other hand, the non-intercalative mode of binding results in bending of the DNA helix reduces the length, which in turn displays a reduction in viscosity [49]. A slight change in the 
DNA viscosity can be attributed to the electrostatic or groove mode of binding. The overall effect on viscosity can be seen by plotting specific viscosity versus [complex]/[DNA]. The plot predicts that the $\mathrm{C} 1$ and $\mathrm{C} 2$ significantly reduce the viscosity, which suggests that mainly an intercalative mode of binding (Fig. 10). The complex C3 and C4 show minimal effect on DNA viscosity, indicate probably through groove binding. These results go in the same line as observed in the spectral assay.

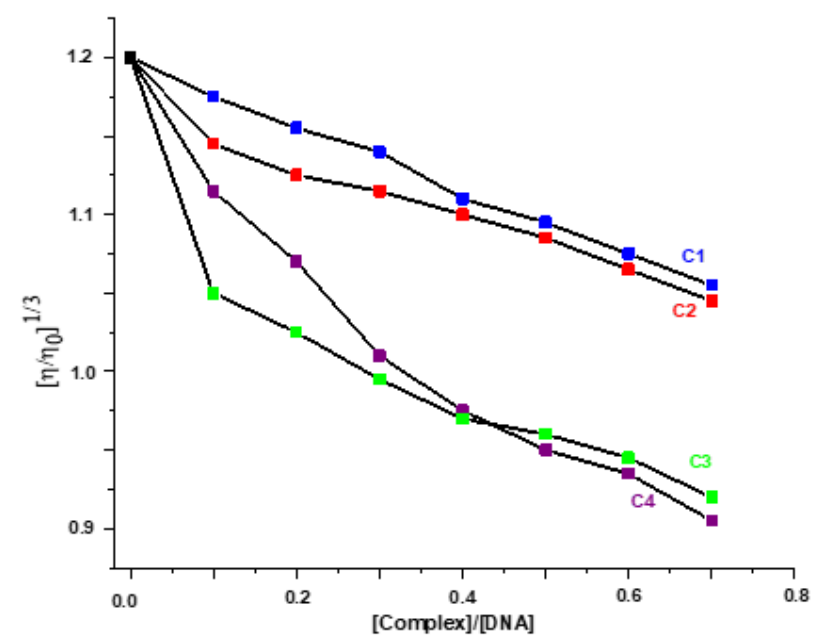

Figure 10. The increasing amount of complexes effect the relative viscosity of CT-DNA at $28^{\circ} \mathrm{C}$.

\subsubsection{DNA incision studies.}

An electrophoretic gel method was used to monitor the transition from naturally occurring circularly closed covalent form (form I) to the nicked circular form (form II) of pBR322 DNA after incubation with metal complex [50]. These transitions will be observed for all the complexes irrespective of the concentration of the sample solution during the incubation period. Relaxation of Supercoiled pBR322 DNA into nicked and linear form (form II) gives a quantitative measurement of DNA cleavage efficiency of complexes in gel agarose medium. Intercalation of metal complexes with DNA can damage supercoiled form with a decrease in its mobility and can be visualized separately as Uv photographic image. On the other hand, weak electrostatic interaction does not significantly affect the supercoiled form of pBR322, so no change in its mobility rate under an electrophoretic gel medium [51]. The nuclease activity of the complex $\mathrm{C} 4$ was scanned through a gel electrophoretic mobility assay with a concentration of $40 \mu \mathrm{M}$, as depicted below (Fig. 11). From the figure, it is clear that there are no significant changes in mobility for controls. In the line of overall nuclease activity $\mathrm{C} 4$ shows promising cleavage properties in the presence of $\mathrm{H}_{2} \mathrm{O}_{2}$ attributed to electrostatic interaction with pBR322 and due to the formation of molecular oxygen or hydroxyl radical. The formation of hydroxyl radical was confirmed by the reduction in the nuclease activity upon the addition of DMSO [52]. Based on these data, it is concluded that the $\mathrm{C} 4$ has appreciable capability in converting supercoiled form to nicked circular form of DNA.

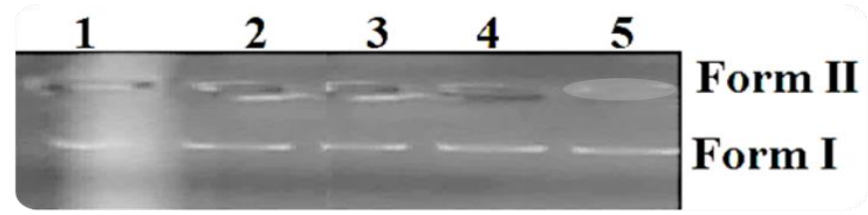

Figure 11. Cleave of pBR 322 DNA by complex C4. Lane 1: DNA + control Plasmid; lane 2: C4 complex alone $40 \mu \mathrm{M}$; lane 3: Hydrogen peroxide $(1 \mathrm{mM})$ alone; lane 4: DNA + C4 complex $(20 \mu \mathrm{M})+$ Hydrogen peroxide $(1 \mathrm{mM})$; lane $5:$ DNA + C4 complex $(40 \mu \mathrm{M})+$ Hydrogen peroxide $(1 \mathrm{mM})$. 


\subsubsection{Pharmacology}

\subsubsection{In vitro cytotoxic activity of complexes.}

3.8.4.1.1. studies of cell growth suppression using MTT probe.

The primary examination of investigated drugs was carried out to mark as a potential suppressor of cancerous cells; we are implementing the two new benzothiazole-based imine base complexes C2 and C4 via an in vitro method using MTT assay anticancer efficacy [53]. The cytotoxicity of the synthesized complexes was scanned on a panel of cancer cell lines and is displayed in terms of IC50 values, as shown in Table 3. Compared with C1 and C3, complex $\mathrm{C} 2$ and $\mathrm{C} 4$ show better in vitro inhibiting properties against all cancer cell lines (EAC, A549, NIH3T3, MCF-7) with incremental concentration $(5,10,15,20,25 \mu \mathrm{M})$ of C2 and C4 for 24 hours separately. The tested cells indicate that more than $50 \%$ were viable in $15 \mu \mathrm{M}$ concentration while at $\geq 20 \mu \mathrm{M}$ cells show variability in their viability as shown in Figures 12C and 12D. EAC cell line is more sensitive to C2 and C4, followed by A549, NIH3T3, and MCF-7. Further, no effect on cellular suppression was seen in the case of free ligand and DMSO. Since C2 and C4 show more sensitive cellular viability in their action compared to $\mathrm{C} 1$ and $\mathrm{C} 3$, we continued our in vivo studies with complex $\mathrm{C} 2$ and $\mathrm{C} 4$.

Table 3. IC50 data for complexes C1-C4 and 5-fluorouracil against 5 human cancer cell lines (NV stands not

\begin{tabular}{|c|c|c|c|c|}
\hline Vehicle code & A549 & NIH-3T3 & MCF-7 & EAC \\
\hline C1 & $\begin{array}{c}27 \pm 2.5 \\
\text { (less viable) }\end{array}$ & $\begin{array}{l}47.3 \pm 3.5 \\
\text { (less viable) }\end{array}$ & $\begin{array}{c}35 \pm 2.7 \\
\text { (less viable) }\end{array}$ & $\begin{array}{c}29 \pm 2.8 \\
\text { (less viable) }\end{array}$ \\
\hline $\mathrm{C} 2$ & $14 \pm 2.5$ & $15.4 \pm 2.8$ & $14.6 \pm 2.2$ & $12.1 \pm 2.3$ \\
\hline $\mathrm{C3}$ & $24 \pm 2.5$ & $36.5 \pm 3.5$ & $49.6 \pm 2.7$ & $38 \pm 2.9$ \\
\hline $\mathrm{C4}$ & $11.3 \pm 2.5$ & $13.4 \pm 3.6$ & $12.7 \pm 2.1$ & $9.4 \pm 2.2$ \\
\hline 5-fluorouracil & $5.2 \pm 0.2$ & $4.5 \pm 0.5$ & $5.1 \pm 0.4$ & $6.2 \pm 0.3$ \\
\hline BMM & NV & $\mathrm{NV}$ & $\mathrm{NV}$ & $\mathrm{NV}$ \\
\hline $\begin{array}{l}\text { Vehicle control } \\
\text { (0.1\%DMSO) }\end{array}$ & $\mathrm{NV}$ & $\mathrm{NV}$ & $\mathrm{NV}$ & $\mathrm{NV}$ \\
\hline
\end{tabular}

3.8.4.1.2. Studies of effect on Cancer metastasis - cellular adhesion and cellular migration.

Cancer cells are always prone to undergo dislocation from the site of their origin to tissues and organs called cancer metastasis. Cancer metastasis is a fundamental hallmark in regulating cell movement into the bloodstream [54]. Further, analysis of growth suppression activity of C2 and C4 was carried out in accordance with IC50 values on respective cancer cell panels. The behavior of complex $\mathrm{C} 2$ was tested at the concentration of $14 \mu \mathrm{M}, 15.4 \mu \mathrm{M}, 14.6 \mu \mathrm{M}$ and 12.1 $\mu \mathrm{M}$ and $\mathrm{C} 4$ at $11.3 \mu \mathrm{M}, 13.4 \mu \mathrm{M}, 12.7 \mu \mathrm{M}$, and 9.4 $\mu \mathrm{M}$ against A549, NIH3T3, MCF-7, and EAC, respectively. Based on the IC50 values, cancer cell migration and cell adhesion studies were carried out, and it is found that the complex $\mathrm{C} 2$ inhibited cell adhesion by about 33.3$42.4 \%$ (Figure $\mathrm{C}$ ) and $\mathrm{C} 4$ by about $40-63.6 \%$. The cell migration assay was also carried out with consideration of IC50 values. Therefore, complex $\mathrm{C} 2$ prevents the process of cell migration by about $14 \mu \mathrm{M}(37.14 \%), 15.4 \mu \mathrm{M}(50.81 \%), 14.6 \mu \mathrm{M}(29.85 \%)$, and $12.1 \mu \mathrm{M}$ (47.05\%) (Figure D) and $\mathrm{C} 4$ at $11.3 \mu \mathrm{M}(42.85 \%), 13.4 \mu \mathrm{M}(63.93 \%), 12.7 \mu \mathrm{M}(43.28 \%)$ and $9.4 \mu \mathrm{M}(60.29 \%)$ against A549, NIH3T3 and MCF-7 and EAC respectively (Fig. 12D). This study concludes that the complex $\mathrm{C} 4$ has a more potential metastatic controller by affecting the 
adhesion properties of cancer cells compared to C2. With respect to cell migration, the degree of inhibition varied with the nature of cell lines [55].

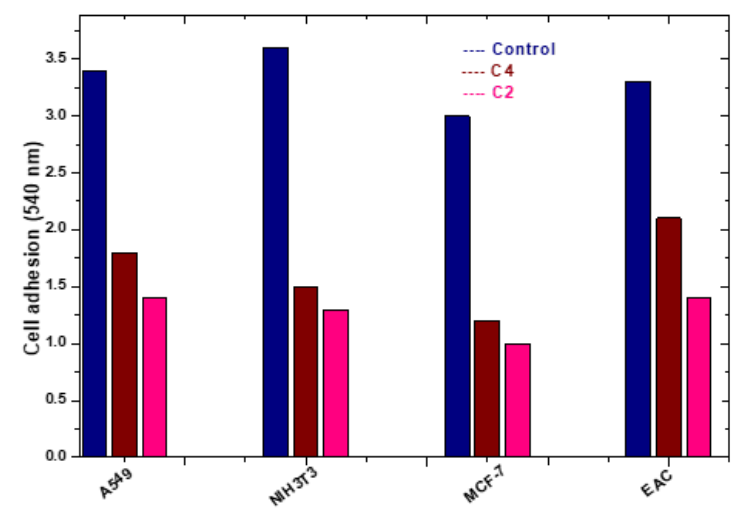

(Fig. C)

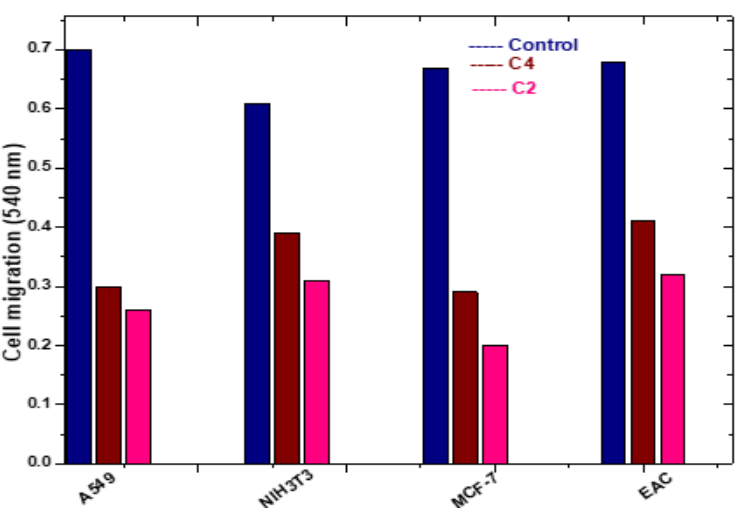

(Fig. D)

Figure 12. Screening of potent anti-proliferative ligand and complexes in vitro. The IC50 value of cytotoxic ligand BMM and complexes (C2 and C4) were determined using MTT assay methods against various cell lines such as A549, NIH-3T3, MCF-7, and EAC.

3.8.4.2. In vivo chronic Toxicity assay of $\mathrm{C} 2$ and $\mathrm{C} 4$ complex.

\subsection{Hematological and serum profile parameter.}

To evaluate the safety measurement in terms of the concentration of complexes $\mathrm{C} 2$ and $\mathrm{C} 4$, we examined their chronic toxicity in male as well as female mice. The hematology examination reveals that both complexes $\mathrm{C} 2$ and $\mathrm{C} 4$ increased the count of red blood cells (RBC) and white blood cells (WBC) in male mice, including hemoglobin, a significant change in the number of platelets and neutrophils for the complex $\mathrm{C} 4$ (Figure E). Complex C4 is more potent than the complex $\mathrm{C} 2$ in increasing the count of these cells may be due to subsequent involvement of the complex in stimulating bone marrow [3, 56, 57].

In liver function analysis (Figure F), both complexes do not show any significant changes in liver functional mechanism except SGOT (Serum Glutamic Oxaloacetic Transaminase), which was slightly enhanced by both complexes with a concomitant decrease in blood glucose levels. The complexes can not be administered clinically to patients suffering from hypoglycemia. An increased level of SGPT (Serum Glutamic Pyruvic Transaminase), CGT (Gamma- Glutamyl Transferase), ALP (Alkaline Phosphatase), and bilirubin in male and female mice are indicated by both the complex C2 and C4 [1, 58].

Further, all the complexes enhanced urea levels significantly in male and female mice. Still, no changes are observed, as in the case of creatinine, and uric acid levels obtained renal function assay (Figure 13H).

The effect of the complex C2 and C4 on lipid profile displayed (Fig. 13G) indicates that all complexes enhance triglycerides, cholesterol, LDL, VLDL levels but shrink HDL levels to a certain extent in both males and female mice. The complex $\mathrm{C} 2$ and $\mathrm{C} 4$ induce mild hepatotoxicity without altering bilirubin level, the hallmark of anticancer complexes. The complexes are not clinically safe. Hence, they are not administered to patients already suffering from hyperlipidemia and heart problems [1, 59, 60]. 

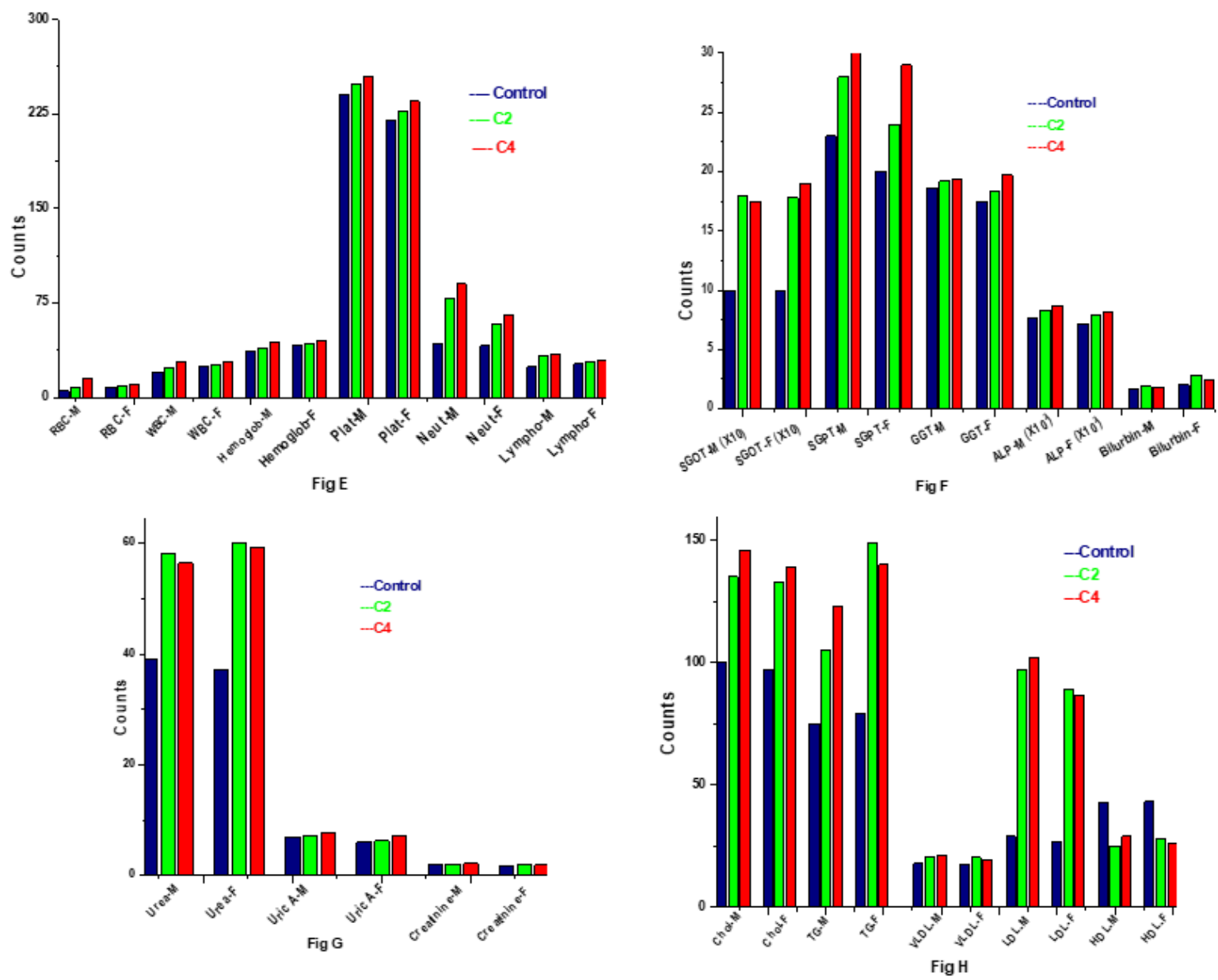

Figure 13. Hematological and serum profile of complexes $\mathrm{C} 2$ and $\mathrm{C} 4$. Fig. E Effect of complex $\mathrm{C} 2$ and $\mathrm{C} 4$ on blood profile. Fig. F Biochemical parameters of liver function. Fig. G Effect of complex C2 and C4 on biochemical parameters of Renal function. Fig H Effect of complex C2 and C4 on lipid profile. Statistical analysis was carried out by using two-way ANOVA in comparison with Control( $\mathrm{C}), \mathrm{n}=4,(\mathrm{p}<0.05$; \# $\mathrm{p}<0.01$; \#\# $\mathrm{p}<$ 0.005; \#\#\# $\mathrm{p}<0.001)$ including Dunnet test as the post - hoc test. A-M and A-F denote adult male and adult female mice, respectively.

\section{Conclusion}

This article has designed and tailored a new benzothiazole-derived imine base complexes of $\mathrm{Co}(\mathrm{III})$ and $\mathrm{Ru}(\mathrm{III})$ metal ions as potent biological entities. All the complexes were scanned for DNA binding propensity and cleavage studies, the primary hallmark for metal-based anticancer pharmacore. The complex $\mathbf{C 4}$ has more binding efficacy compared to C2 with CT DNA which may be due to the interaction of $\pi$-orbital of 1,10 phenanthroline with nucleotide base of DNA. Furthermore, the Nuclease activity of the complex C2 and C4 was examined on pBR322 DNA, and their plausible mechanistic pathway was elucidated with radical scavengers. DNA biocidal assay makes a point regarding their conversion of closed circular structure into nicked linear form through intercalation mode of binding by $\mathbf{C 4}$ more efficiently compared to $\mathbf{C 2}$ complex. The in vivo toxicity of $\mathbf{C 2}$ and $\mathbf{C 4}$ complexes and free ligand was examined against four different cancer cell lines. The outcome displayed that the complex $\mathbf{C 4}$ has profound cell viability compared to $\mathbf{C} 2$ on EAC cell line, in comparison with a reference drug 5-fluorouracil according to IC50 values. In the continuation of the work, we have analyzed the cellular metastasis with due interest to cell adhesion and cell migration properties of different cancer cell lines in the presence of complex C2 and C4. Our analysis shows that complex $\mathbf{C 4}$ showed promising anti-metastatic potential by preventing cell migration and cell adhesion of cancer cells. Overall, the present investigation requires more in 
vivo confirmatory experiments to judge the complexes as a promising pharmacophore for cancer treatment.

\section{Funding}

Not available.

\section{Acknowledgment}

The author would like to extend their sincere gratitude to IOE, Vijnana Bhavan, University of Mysore, Mysuru, and Cell kraft biotech, Bangalore, for analytical and biological facilities, respectively.

\section{Conflict of interest}

The author declares no conflict of interest.

\section{References}

1. Afzal Hussain.; Mohamed, F.A.; Tabish Rehaman, Md.; Azmat Ali, K.; Perwez, A.S.; Rais Ahmad, K. Evaluation of Transition Metal Complexes of Benzimidazole-derived Scaffold as Promising Anticancer Chemotherapeutics. Molecules 2018, 23, 1232, https://doi.org/10.3390/molecules23051232.

2. Rupinder, K. G.; Ravindra, K. R.; Jitender Baiwal. Recent Advances in the Chemistry and Biology of Benzothiazoles-Review article. Arch.Pharm. Chem.Life Sci. 2015, 348, 155-178, https://doi.org/10.1002/ardp.201400340.

3. Rahman, A.; Imtiyaz, Y.; Mohd A.; Saurabh, S.; Srikrishn, S.; Farukh, A. Enantiomeric Fluoro-substituted Benzothiazole Schiff Base-valine $\mathrm{Cu}(\mathrm{II}) / \mathrm{Zn}$ (II) Complexes as Chemotherapeutic Agents: DNA Binding Profile, Cleavage activity, MTT assay and Cell imaging studies. Journal of Photochemistry and Photobiology B: Biology 2015, 143, 1011-1028, https://doi.org/10.1016/j.jphotobiol.2014.12.027.

4. Safaa Eidin, H.E.; Dina, M. A.; Eman, H.A.; Elham, A.A. Synthesis, spectral, Antimicrobial and Antitumor Assessment of Schiff Base Derived from 2-Aminobenzothiazole and its Transition Metal Complexes, Spectrochemica Acta Part A: Molecular and Biomolecular spectroscopy 2011, 79, 1331-1337, https://doi.org/10.1016/j.saa.2011.04.064.

5. Meenakshi, S.; Gangwar, M.; Gopal, N.; Singh, S. Synthesis, DNA Cleavage and Antimicrobial Activity of 4-Thiazolidinones-benzothiazole Conjugates. Indian Journal of Experimental Biology 2014, 52, 1062-1070, https://www.researchgate.net/publication/268987671.

6. Pereira, G.A.; Massabni, A.C.; Castellano, E.E.; Sodre Costa, L.A.; Fugimura Leite, C.Q.; Pavan, F.R.; Cuin, A. A Broad Study of Two New Promising Antimycobacterial Drugs: $\mathrm{Ag}(\mathrm{I})$ and $\mathrm{Au}(\mathrm{I})$ Complexes with 2-(2thienyl)benzothiazole. Polyhedron 2012, 38, 291-296, https://doi.org/10.1016/j.poly.2012.03.016.

7. Soni, B.; Ranawat, M.S.; Sharma, R.; Bhandari, A.; Sharma, S. Synthesis and Evaluation of Some New Benzothiazole Derivatives as Potential Antimicrobial Agents. European Journal of Medicinal Chemistry 2010, 45, 2938-2942, https://doi.org/10.1016/j.ejmech.2010.03.019.

8. Al-Sound, Y.A.; Al-Sadoni, H.H.; Saeed, B.; Jaber, I.H.; Beni-Khalid, M.O.; Al-Masoudi, N.A.; Tahsin, A.; Colla, P.L.; Busonera, B.; Sanna, T.; Loddo, R. Synthesis and In vitro Anti-proliferative Activity of New Benzothiazole derivatives. Arkivoc 2008, 15, 225-238, https://www.researchgate.net/profile/RobertaLoddo/publication/228662092.

9. Dhairya, B.; Trivedi, J.; Shrey, P.; Mahesha, S.; Shailesh, T.; Abhay, B.; Ashish, R.; Vala, H.; Jignesh, L.; Manisha, P.; Paresh, L.; Loddo, R.; Anamik, S. Synthesis and In vitro Anti-HIV Activity of N-1,3benzo[d]thiazol-2-yl-2-(2-oxo-2H-chromen-4-yl)acetamide Derivatives Using MTT Method. Bioorganic and Medicinal chemistry Letters 2011, 21, 3443-3446, https://doi.org/10.1016/j.bmcl.2011.03.105.

10. Vamsikrishna, N.; Pradeep kumar, M.; Ramesh, G.; Nirmala, G.; Sreenu, D.; Shivaraj. DNA Interactions and Biocidal Activity of Metal Complexes of Benzothiazole Schiff Bases: Synthesis, Characterization and Validation. Journal of Chemical Science 2017, 129, 609-622, https://doi10.1007/s12039-017-1273-7. 
11. Joseph, J.; Boomadevi Janaki, G. Synthesis, Structural Characterization and Biological Studies of Copper Complexes with 2-aminobenzothiazole Derivatives. Journal of Material and Environmental Science 2014, 5, 693-704, https://www.jmaterenvironsci.com/Document/vol5/vol5_N3/85-JMES-660-2014-Joseph.pdf.

12. Bradshaw, T.D.; Chua, M.S.; Orr, S.; Matthews, C.S.; Stevens, M.F.G. Mechanism of Acquired Resistance to 2-(4-aminophenyl)benzothiazole. British Journal of Cancer 2000, 83, 270-277, https://doi.org/10.1054/bjoc.2000.1231.

13. Jing, B.; Dong, J.; Xu, T.; Li, L. Synthesis, Crystal Structure, and DNA Interaction of an Oxovanadium(IV) Complex Containing L-valine Schiff Base and 1,10-Phenanthroline. Journal of Coordination chemistry 2013, 66, 520-529, https://doi.org/10.1080/00958972.2013.763939.

14. Balouiri, M.; Sadiki, M.; Ibnsouda, S.K. Methods for In vitro Evaluating Antimicrobial Activity. International Journal of Biological Macromolecules $\mathbf{2 0 1 4}, \quad 66, \quad 166-171$, https://doi.org/10.1016/j.jpha.2015.11.005.

15. Zheng, K.; Liu, F.; Li, Y.T.; Wu, Z.Y.; Yan, C.W. Synthesis and Structure Elucidation of New $\mu$-OxamidoBridged Dicopper(II) Complexes Showing In vitro Anticancer Activity: Evaluation of DNA/Protein-Binding Properties by Experiment and Molecular Docking. Journal of Inorganic Biochemistry 2016, 156, 75-88, https://doi.org/10.1016/j.jinorgbio.2015.12.023.

16. Arjmand, F.; Aziz, M. Synthesis and Characterization of Dinuclear Macrocyclic Cobalt(II), Copper(II) and Zinc(II) Complexes Derived from 2,2,2('),2(')-S,S[bis(bis-N,N-2-thiobenzimidazolyloxalato-1,2-ethane)]: DNA Binding and Cleavage Studies. European Journal of Medicinal Chemistry 2009, 44, 834-844, https://doi.org/10.1016/j.ejmech.2008.05.006.

17. Praveen, S.; Arjmand, F.; Mohapatra, D.K. Zinc(II) Complexes of Pro-Gly and Pro-Leu Dipeptides: Synthesis, Characterization, In vitro DNA Binding and Cleavage Studies. Journal of Photochemistry and Photobiology 2013, 126, 78-86, https://doi.org/10.1016/j.jphotobiol.2013.07.009.

18. Li, Y.; Yang, Z.Y.; Wang, M.F. Synthesis, Characterization, DNA Binding Properties, Fluorescence Studies and Antioxidant Activity of Transition Metal Complexes with Hesperetin-2-hydroxy Benzoyl Hydrazone. Journal of Fluorescence 2010, 20, 891-905, https://doi:10.1007/s10895-010-0635-z.

19. Sedighipoor, M.; Kianfar, A. H.; Mahmood, W. A. K.; Azarian. Synthesis and Electronic Structure of Novel Schiff Bases Ni/Cu (II) Complexes: Evaluation of DNA/Serum Protein Binding by Spectroscopic Studies. Polyhedron 2017, 129, 1-8, https://doi.org/10.1016/j.poly.2017.03.027.

20. Daravath, S.; Rambabu, A.; Vamsikrishna, N.; Ganji, N.; Raj, S. Synthesis, Structural Characterization, Antioxidant, Antimicrobial, DNA Incision Evaluation and Binding Investigation Studies on Copper(II) and Cobalt(II) Complexes of Benzothiazole cored Schiff Bases. Journal of Coordination Chemistry 2019, 95, 121, https://doi:10.1080/00958972.2019.1634263.

21. Prabhakar, B.T.; Khanum, S.A.; Jayashree, K.; Salimath, B.P.; Shashikanth, S. Anti-tumor and Proapoptotic Effect of Novel Synthetic Benzophenone Analogues in Ehrlich ascites tumor cells. Bioorganic \& Medicinal Chemistry 2006, 14, 435-446, https://doi.org/10.1016/j.bmc.2005.08.039.

22. Thamilarasan, V.; Sengottuvelan, N.; Sudha, A.; Srinivasan, P.; Chakkaravarthi, G. Cobalt(III) complexes as potential anticancer agents: Physicochemical, structural, cytotoxic activity and DNA/protein interactions. Journal of Photochemistry and Photobiology B: Biology 2016, 162, 558-569, https://doi.org/10.1016/j.jphotobiol.2016.06.024.

23. Steiner, R. A.; Foreman, D.; Lin, H. X.; Carney, B. K.; Fox, K. M.; Cassimeris, L.; Tyler, L. A. Synthesis, Characterization, Crystal Structures and Biological Activity of Set of Cu(II) Benzothiazole Complexes: Artificial Nucleases with Cytotoxic Activities. Journal of Inorganic Biochemistry 2014, 137, 1-11, https://doi:10.1016/j.jinorgbio.2014.04.002.

24. Sathiyaraj, S.; Butcher, R. J.; Jayabalakrishnan, C. DNA Interaction and Cytotoxicity Studies of Ruthenium(III) Complexes Containing 3-(benzothiazol-2-yliminomethyl)-naphthalen-2-ol Ligand. Journal of Coordination Chemistry 2013, 66, 580-591, https://doi:10.1080/00958972.2013.764995.

25. Jia, L.; Xu, J.; Zhao, X.; Shen, S.; Zhou, T.; Xu, Z.; Huang, J. Synthesis, Characterization, and Antitumor Activity of Three Ternary Dinuclear Copper (II) Complexes with a Reduced Schiff Base Ligand and Diimine coligands in vitro and in vivo. Journal of Inorganic Biochemistry 2016, 159, 107-119, https://doi:10.1016/j.jinorgbio.2016.02.033.

26. Saedi, Z.; Hoveizi, E.; Roushani, M.; Massahi, S.; Hadian, M.; Salehi, K. Synthesis, Characterization, Anticancer Properties and Theoretical Study of Asymmetrical Cd(II)-N2-Schiff Base Complexes. Journal of Molecular Structure 2018, 22, 1021-1024, https://doi:10.1016/j.molstruc.2018.08.072. 
27. Malojirao, V.H.; Vigneshwaran, V.; Thirusangu, P.; Mahmood, R.; Prabhakar, B.T. The Tumor Antagonistic Steroidal Alkaloid Solanidine Prompts the Intrinsic Suicidal Signal Mediated DFF-40 Nuclear Import and Nucleosomal Disruption. Life Sciences 2018, 199, 139-150, https://doi.org/10.1016/j.lfs.2018.03.015.

28. Jana, K.; Das, S.; Puschmann, H.; Debnath, S. C.; Shukla, A.; Mahanta, A. K.; Samanta, B. C. Supramolecular Self-Assembly, DNA interaction, Antibacterial and Cell Viability studies of $\mathrm{Cu}(\mathrm{II})$ and $\mathrm{Ni}(\mathrm{II}) \mathrm{Complexes}$ derived from NNN donor Schiff Base ligand. Inorganica Chimica Acta 2018, 18, 1693-1711, http://dx.doi.org/10.1016/j.ica.2018.12.007.

29. Kumaravel, G.; Ponya Utthra, P.; Raman, N. Exploiting the Biological Efficacy of Benzimidazole Based Schiff Base Complexes with 1-Histidine as a Co-ligand: Combined Molecular Docking, DNA Interaction, Antimicrobial and Cytotoxic Studies. Bioorganic Chemistry 2018, 77, 269-279, https://doi.org/10.1016/j.bioorg.2018.01.024.

30. Ali, S.M.M.; Zakir, H.M.; Shahriar, S.; Sarkar, M.; Dey, A.K.; Nur, H.P.; Jesmin, M. In vivo Anti-cancer Activities of Ni(II)-Benzoin Thiosemicarbazone Complex [Ni(BTSC)2] Against Ehrlich Ascites Carcinoma Cells. Journal of Bio-Science 2018, 23, 77-88, https://doi.org/10.3329/jbs.v23i0.37470.

31. Prakasha, G.; Shiva Prasad, K.; Ibrahim, S.; Revanasiddappa H.D. Novel Benzimidazole Derived ImineBased Ligand and its $\mathrm{Co}$ (III), Ni(II), Cu(II) and Pt(II) Complexes: Chemical Synthesis, Structure, Antimicrobial, DNA Interaction Studies and Nuclease Activity. Letters in Applied Nanobioscience 2020, 9 , 1655-1672, https://doi.org/10.33263/LIANBS94.16551672.

32. Savithri, K.; Kumar, B.C.V.; Vivek, H.K.; Revanasiddappa, H.D. Synthesis and Characterization of Cobalt(III) and Copper(II) Complexes of 2-((E)-(6-Fluorobenzo[d]thiazol-2-ylimino) methyl)-4chlorophenol: DNA Binding and Nuclease Studies-SOD and Antimicrobial Activities. International Journal of Spectroscopy 2018, 1-15, https://doi.org/10.1155/2018/8759372.

33. Daniel, V.P.; Murukan, B.; Sindhukumari, B.; Mohanan, K. Synthesis, Spectroscopic Characterization, Electrochemical Behavior, Reactivity and Antibacterial Activity of Some Transition Metal Complexes with 2-(N-salicylideneamino)-3-carboxyethyl-4,5-dimethylthiophene. Spectrochemica Acta Part A 2008, 70, 403410, https://doi.org/10.1016/j.saa.2007.11.003.

34. Chohan, Z. H.; \& Supuran, C. T.; Antibacterial Co(II) and Ni(II) Complexes of Benzothiazole-Derived Schiff Bases-Synthesis and Reactivity in Inorganic and Metal-Organic Chemistry 2002, 32, 1445-1461, https://doi.org/10.1081/sim-120014861.

35. Priya, N. P.; Arunachalam, S.; Manimaran, A.; Muthupriya, D.; Jayabalakrishnan, C. Mononuclear Ru(III) Schiff Base Complexes: Synthesis, Spectral, Redox, Catalytic and Biological Activity Studies. Spectrochimica Acta Part A: Molecular and Biomolecular Spectroscopy 2009, 72, 670-676, https://doi.org/10.1016/j.saa.2008.10.028.

36. Alturiqi, A. S.; Alaghaz, M. A.; Ammar, R. A.; Zayed, M. E. Synthesis, Spectral Characterization, and Thermal and Cytotoxicity Studies of $\mathrm{Cr}(\mathrm{III}), \mathrm{Ru}(\mathrm{III}), \mathrm{Mn}(\mathrm{II}), \mathrm{Co}(\mathrm{II}), \mathrm{Ni}(\mathrm{II}), \mathrm{Cu}(\mathrm{II})$, and $\mathrm{Zn}$ (II) Complexes of Schiff Base Derived from 5-Hydroxymethylfuran-2-carbaldehyde. Journal of Chemistry 2018, 2018, 1-17, https://doi.org/10.1155/2018/5816906.

37. Maikoo, S.; Margaret Kirkpatrick Dingle, L.; Chakraborty, A.; Xulu, B.; Lesley Edkins, A.; Noel Booysen, I. Synthetic, Characterization and Cytotoxic Studies of Ruthenium Complexes with Schiff Bases Encompassing Biologically Relevant Moieties. Polyhedron 2020, 184, 114569, https://doi.org/10.1016/j.poly.2020.114569.

38. More, G.; Raut, D.; Aruna, K.; Bootwala, S.; Synthesis, Spectroscopic Characterization and Antimicrobial Activity Evaluation of New Tridentate Schiff Bases and their Co(II) Complexes. Journal of Saudi Chemical Society 2017, 21, 954-964, https://doi.org/10.1016/j.jscs.2017.05.002.

39. Sampath, K.; Sathiyaraj, S.; Jayabalakrishnan, C. DNA Interaction, Antioxidant, and In vitro Antitumor Activity of Binuclear Ruthenium(III) Complexes of Benzothiazole-Substituted Ferrocenyl Thiosemicarbazones. Medicinal Chemistry Research 2013, 23, 958-968, https://doi.org/10.1007/s00044013-0698-X.

40. Jawoor, S. S.; Patil, S. A.; Toragalmath, S. S. Synthesis and Characterization of Heteroleptic Schiff Base Transition Metal Complexes: A Study of Anticancer, Antimicrobial, DNA Cleavage and Anti-TB activity. Journal of Coordination Chemistry 2018, 71, 271-283, https://doi.org/10.1080/00958972.2017.1421951.

41. Rambabu, A.; Pradeep Kumar, M.; Tejaswi, S.; Vamsikrishna, N.; \& Shivaraj. DNA Interaction, Antimicrobial Studies of Newly Synthesized Copper (II) Complexes with 2-amino-6(trifluoromethoxy)benzothiazole Schiff Base Ligands. Journal of Photochemistry and Photobiology B: Biology 2016, 165, 147-156, https://doi.org/10.1016/j.jphotobiol.2016.10.027. 
42. Shekhar, S.; Khan, A.; M., Sharma, S.; Sharma, B.; \& Sarkar, A. Schiff Base Metallodrugs in Antimicrobial and Anticancer chemotherapy applications: A Comprehensive Review. Emergent Materials 2021, https://doi.org/10.1007/s42247-021-00234-1.

43. Vamsikrishna, N.; Kumar, M. P.; Tejaswi, S.; Rambabu, A. DNA Binding, Cleavage and Antibacterial Activity of Mononuclear $\mathrm{Cu}(\mathrm{II}), \mathrm{Ni}(\mathrm{II})$ and $\mathrm{Co}(\mathrm{II})$ Complexes Derived from Novel Benzothiazole Schiff Bases. Journal of Fluorescence 2016, 26, 1317-1329, https://doi.org/10.1007/s10895-016-1818-z.

44. Dhanaraj, C. J.; Hassan, I. U.; Johnson, J.; Joseph, J.; Joseyphus, R. S. Synthesis, Spectral Characterization, DNA Interaction, Anticancer and Molecular Docking Studies on Some Transition Metal Complexes with Bidentate Ligand. Journal of Photochemistry and Photobiology B: Biology 2016, 162, 115-124, https://doi:10.1016/j.jphotobiol.2016.06.032.

45. Aravath, S.; Rambabu, A.; Shankar, D. S.; Raj, S. Structure Elucidation of Copper(II), Cobalt(II) and Nickel(II) Complexes of Benzothiazole Derivatives: Investigation of DNA Binding, Nuclease Efficacy, Free Radical Scavenging and Biocidal properties. Chemical Data Collections 2019, 24, 100293, https://doi.org/10.1016/j.cdc.2019.100293.

46. Vamsikrishna, N.; Daravath, S.; Ganji, N.; Pasha, N.; \& Shivaraj. Synthesis, Structural Characterization, DNA Interaction, Antibacterial and Cytotoxicity Studies of Bivalent Transition Metal Complexes of 6aminobenzothiazole Schiff Base. Inorganic Chemistry Communications 2020, 113, 107767, https://doi.org/10.1016/j.inoche.2020.107767.

47. Elsayed, S. A.; El-Gharabawy, H. M.; Butler, I. S.; Atlam, F. M. Novel Metal Complexes of 3Acetylcoumarin-2-hydrazinobenzothiazole Schiff Base: Design, Structural Characterizations, DNA Binding, DFT Calculations, Molecular Docking and Biological Studies. Applied Organometallic Chemistry 2020, 5643, 1-18, https://doi.org/10.1002/aoc.5643.

48. Lari, M.; Martínez-Alonso, M.; Busto, N.; Manzano, B. R.; Rodríguez, A. M.; Acuna, M. I.; García, B. Strong Influence of Ancillary Ligands Containing Benzothiazole or Benzimidazole Rings on Cytotoxicity and Photoactivation of $\mathrm{Ru}(\mathrm{II})$ Arene Complexes. Inorganic Chemistry 2018, https://doi.org/10.1021/acs.inorgchem.8b02299.

49. Fu, X.-B.; Weng, G.-T.; Liu, D.-D.; \& Le, X.-Y. Synthesis, Characterization, DNA Binding and Cleavage, HSA Interaction and Cytotoxicity of a New Copper(II) Complex Derived from 2-(2'-pyridyl)benzothiazole and Glycylglycine. Journal of Photochemistry and Photobiology A: Chemistry 2014, 276, 83-95, https://doi:10.1016/j.jphotochem.2013.12.002.

50. Abdel Aziz, A. A.; Elbadawy, H. A. Spectral, Electrochemical, Thermal, DNA Binding Ability, Antioxidant and Antibacterial Studies of Novel Ru(III) Schiff Base Complexes. Spectrochimica Acta Part A: Molecular and Biomolecular Spectroscopy 2014, 124, 404-415, https://doi.org/10.1016/j.saa.2014.01.050.

51. Anu, D.; Naveen, P.; Rath, N. P.; Kaveri, M. V. Palladium (II) complexes containing substituted thiosemicarbazones. Synthesis, spectral characterization, X-ray crystallography, biomolecular interactions and in vitro cytotoxicity. Journal of Molecular Structure 2020, 1206, 127703, https://doi.org/10.1016/j.molstruc.2020.127703.

52. Chaurasia, M.; Tomar, D.; Chandra, S. Synthesis, Spectroscopic Characterization and DNA Binding Studies of $\mathrm{Cu}(\mathrm{II})$ Complex of Schiff Base Containing Benzothiazole Moiety. Journal of Taibah University for Science 2019, 13, 1050-1059, https://doi.org/10.1080/16583655.2019.1681724.

53. Mudavath, R.; Ushaiah, B.; Kishan, P.; Molecular Docking, QSAR Properties and DNA/BSA Binding, Proliferative Studies of 6- Methoxy Benzothiazole Imine Base and its Metal Complexes. Journal of Biomolecular Structure and Dynamics 2019, 38, 1-20, https://doi.org/10.1080/07391102.2019.1647878.

54. Steiner, R. A.; Foreman, D.; Lin, H. X.; Carney, B. K.; Fox, K. M. Synthesis, Characterization, Crystal Structures and Biological Activity of Set of $\mathrm{Cu}(\mathrm{II})$ Benzothiazole Complexes: Artificial Nucleases with Cytotoxic Activities. Journal of Inorganic Biochemistry 2014, 137, 1-11, https://doi.org/10.1016/j.jinorgbio.2014.04.002.

55. Saedi, Z.; Hoveizi, E.; Roushani, M.; Massahi, S.; Hadian, M.; Salehi, K. Synthesis, Characterization, Anticancer Properties and Theoretical Study of Asymmetrical Cd(II)-N2-Schiff Base Complexes. Journal of Molecular Structure 2018, 1176, 207-216, https://doi.org/10.1016/j.molstruc.2018.08.072.

56. Raja, G.; Butcher, R. J.; \& Jayabalakrishnan, C. Studies on Synthesis, Characterization, DNA Interaction and Cytotoxicity of Ruthenium(II) Schiff Base Complexes. Spectrochimica Acta Part A: Molecular and Biomolecular Spectroscopy 2012, 94, 210-215, https://doi.org/10.1016/j.saa.2012.03.035. 
57. Mahmoud, W. H.; Deghadi, R. G.; \& Mohamed, G. G. Spectroscopic and Thermal Characterization of Biologically and Anticancer Active Novel Schiff Base Metal Complexes. Research on Chemical Intermediates 2016, 42, 7869-7907, https://doi.org/10.1007/s11164-016-2567-y.

58. Purkait, K.; Mukherjee, A. Cytotoxicity and Reactivity of a Redox Active 1,4-Quinone-Pyrazole Compound and its $\mathrm{Ru}(\mathrm{II})$-p-Cymene Complex. Inorganica Chimica Acta 2020, 502, 119361, https://doi.org/10.1016/j.ica.2019.119361.

59. Inan, A.; Sunbul, A. B.; Ikiz, M.; Tayhan, S. E.; Bilgin, S.; Elmastaş, M.; Ispir, E. Half-Sandwich Ruthenium (II) Arene Complexes Bearing the Azo-Azomethine Ligands: Electrochemical, Computational, Antiproliferative and Antioxidant Properties. Journal of Organometallic Chemistry 2018, 870, 76-89, https://doi.org/10.1016/j.jorganchem.2018.06.014.

60. Rao, N. N.; kishan, E.; Gopichand, K.; Nagaraju, R.; Ganai, A. M.; Rao, P. V. Design, Synthesis, Spectral Characterization, DNA Binding, Photo Cleavage and Antibacterial Studies of Transition Metal Complexes of Benzothiazole Schiff base. Chemical Data Collections 2020, 27, 100368 , https://doi.org/10.1016/j.cdc.2020.100368. 


\section{Supplementary materials}

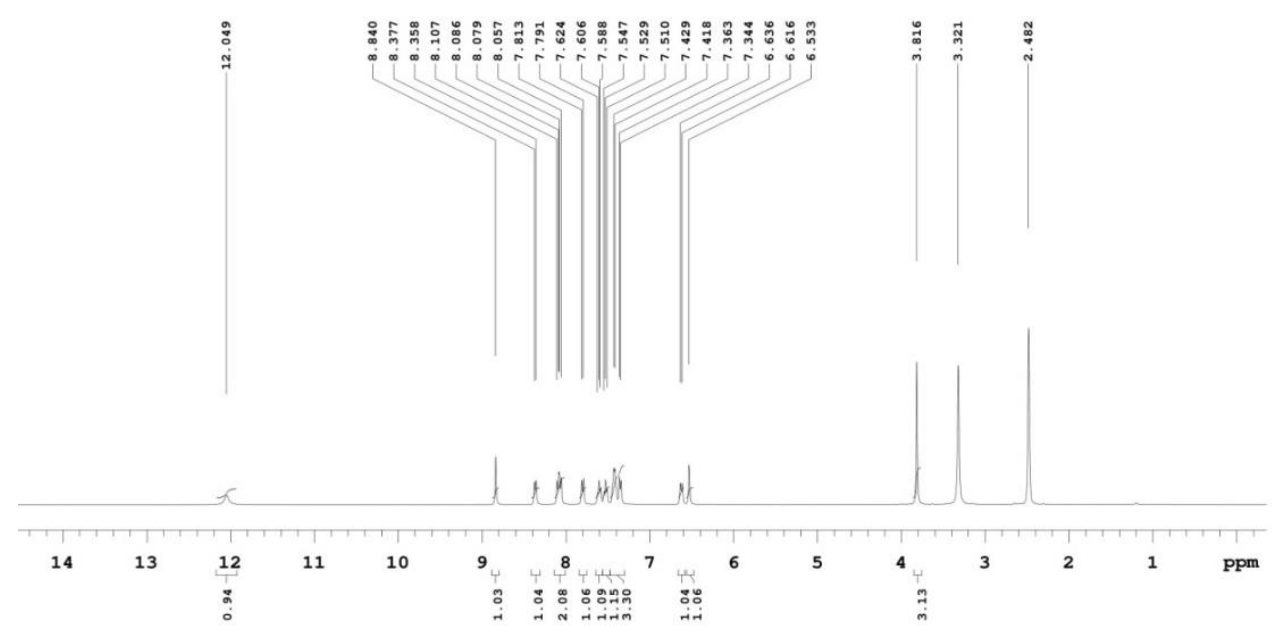

Figure S1. ${ }^{1} \mathrm{H}-\mathrm{NMR}$ spectrum of BMM.

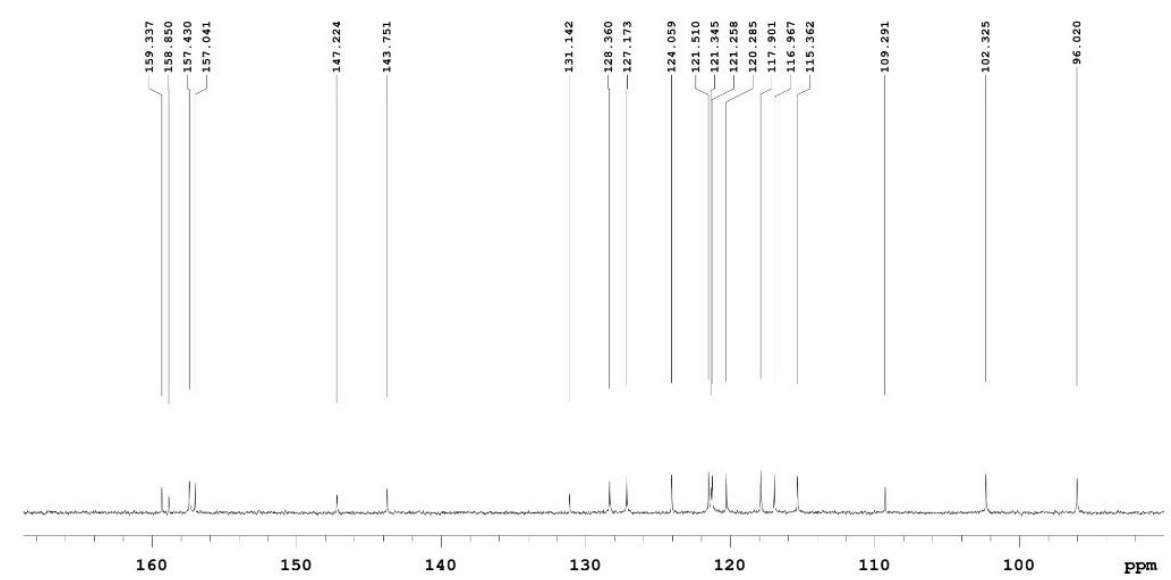

Figure S2. ${ }^{13} \mathrm{C}$ - NMR spectrum of BMM.

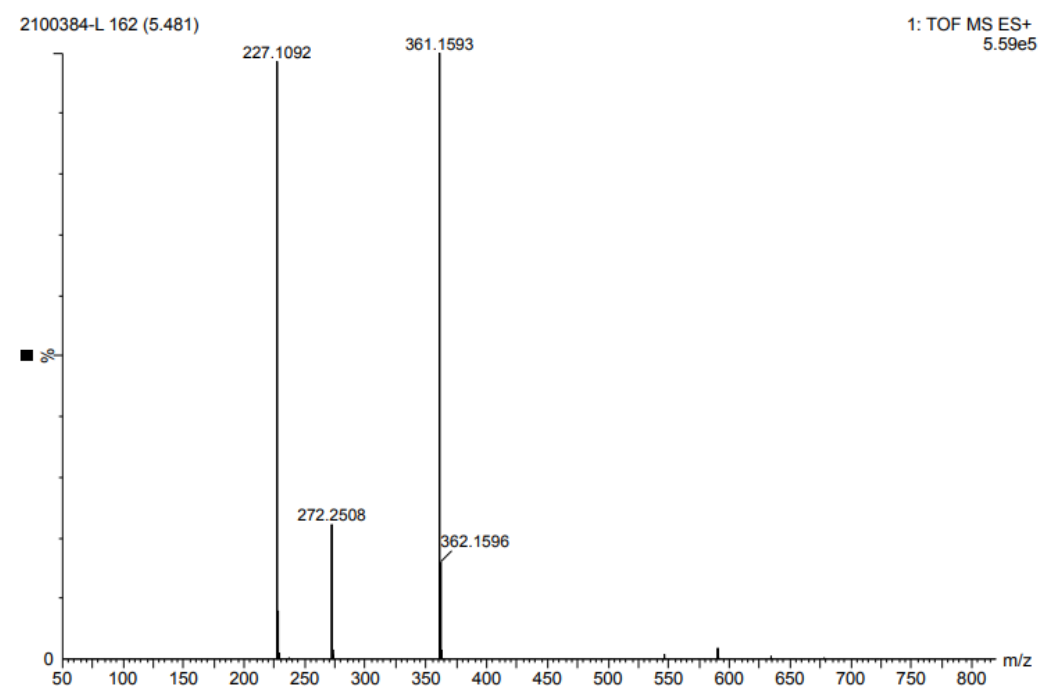

Figure S3. Mass spectrum of BMM. 


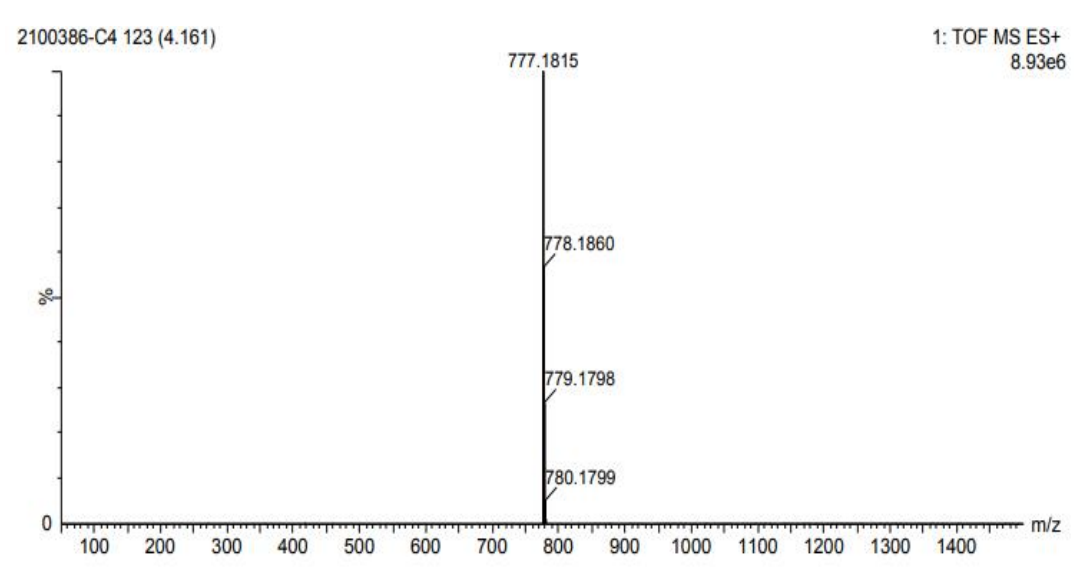

Figure S4. Mass spectrum of C1.

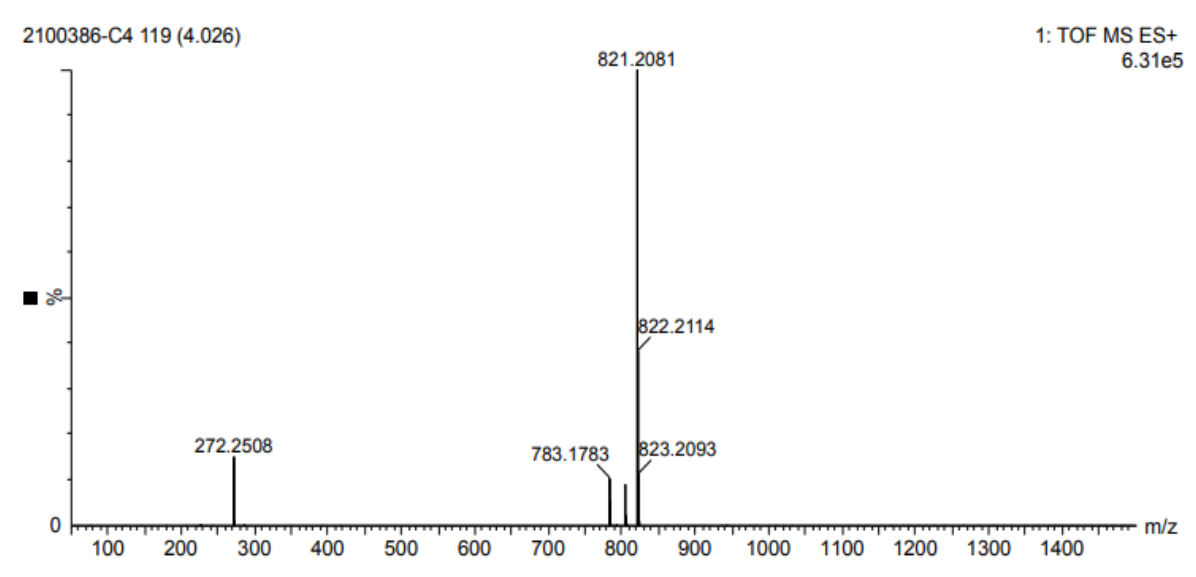

Figure S5. Mass spectrum of C2.

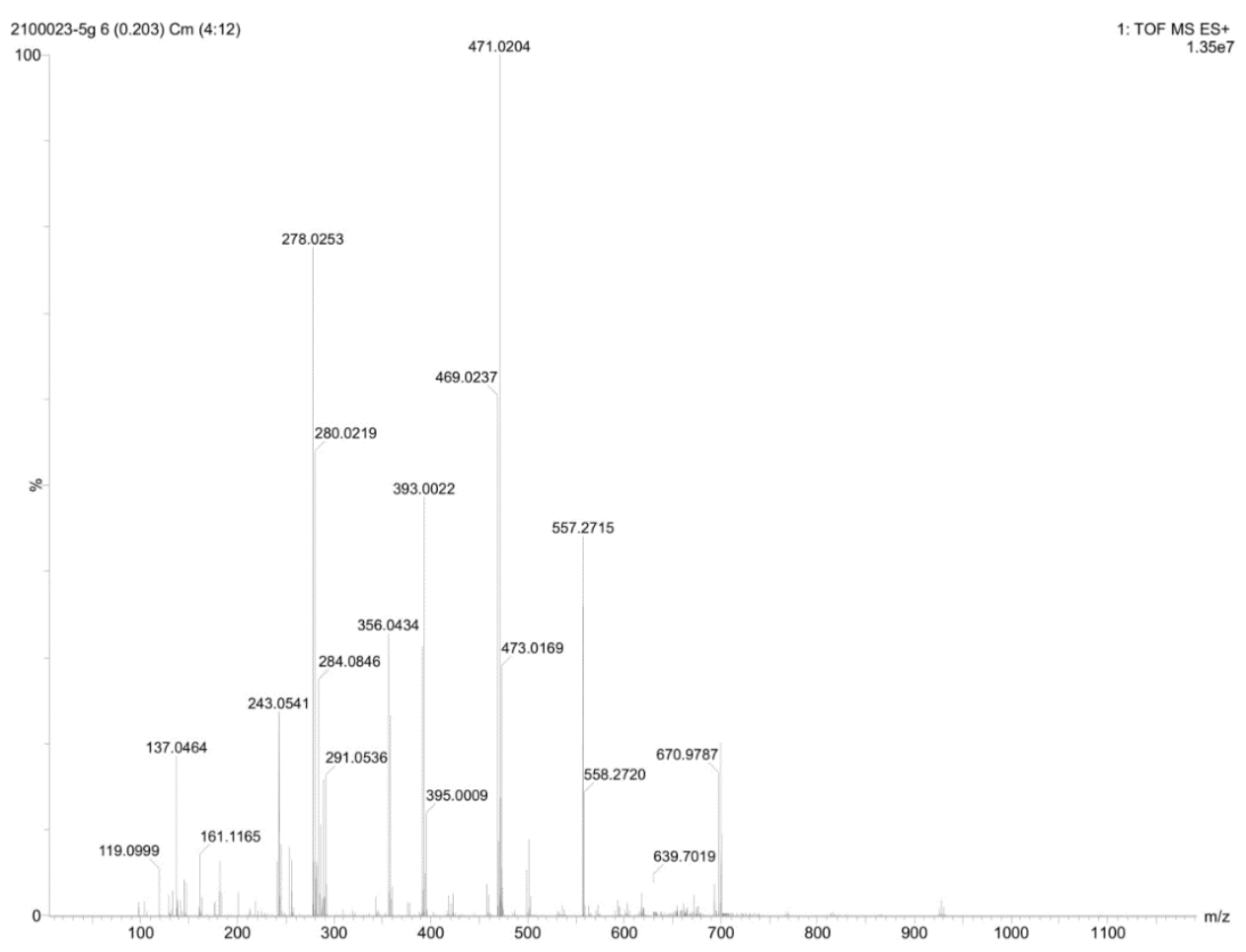

Figure S6. Mass spectrum of C3. 


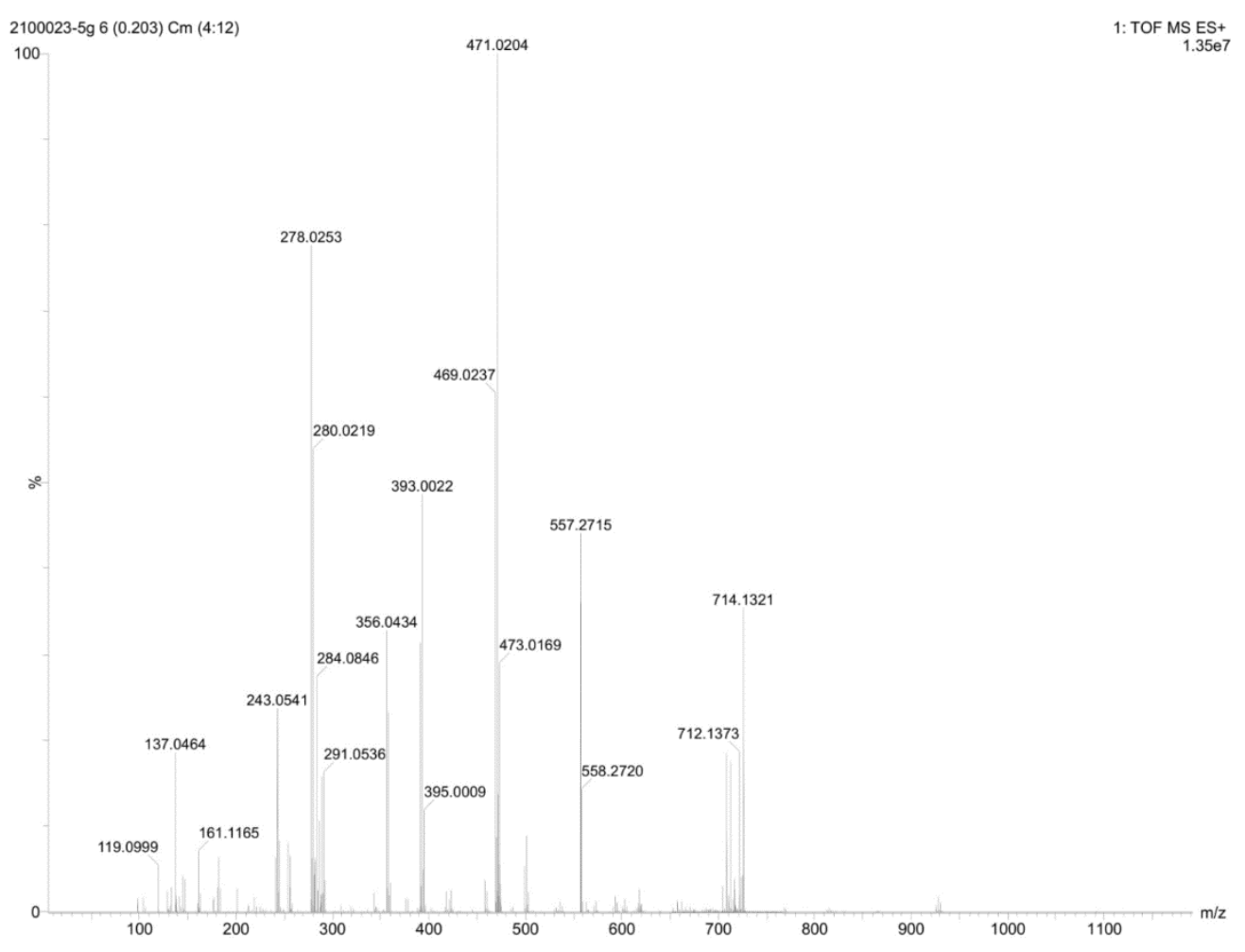

Figure S7. Mass spectrum of C4. 